\title{
52. MINERALOGY AND GEOCHEMISTRY OF ALTERATION PRODUCTS IN HOLES 417A AND 417D BASEMENT SAMPLES (DEEP SEA DRILLING PROJECT LEG 51)
}

\author{
Thierry Juteau, Yves Noack, and Hubert Whitechurch, Université Louis Pasteur, Laboratoire de Mineralogie et Pétrographie, \\ 1 rue Blessig, 67084 Strasbourg, France \\ and \\ Chantal Courtois, Université de Paris-Sud, Laboratoire de Géochimie des Roches Sédimentaires, Bâtiment 504, \\ 91405 Orsay, France
}

\begin{abstract}
The striking difference between the basalts of Hole 417A (strongly altered) and those of Hole 417D (slightly altered) is one of the main discoveries of Legs 51-52. After a macroscopic description of the two basaltic sections, the authors describe the mineralogy of alteration in the two holes. In Hole 417D, the pillow margins exhibit a nice concentric zoning, with a hyaloclastic zone, a glassy zone, a variolitic zone, a spherolitic zone, and the pillow core. Fresh black and brilliant glass is abundant; it is partly altered mainly in the hyaloclastic zone (delicate concentric rims of brown palagonite) and in the variolitic zone (yellow fibropalagonite). X-ray diffraction patterns indicate a dioctahedral smectite (montmorillonite type) for the palagonite to a depth of 475 meters, and a trioctahedral smectite (saponite type) for deeper samples. SEM chemical profiles in the palagonite rims of hyaloclastic fragment indicate a strong enrichment in $\mathrm{K}$ and $\mathrm{Fe}$ in the outermost layers, suggesting a "protoceladonite" composition for the corresponding smectites. The glassy zone remains remarkably fresh: palagonitic layers developed along cracks are quite similar to the palagonite rims in the hyaloclastic zone. Clinopyroxene and plagioclase phenocrysts are generally devoid of alteration; olivine phenocrysts are completely replaced by calcite, iron oxides, and brown to green smectites. Vesicles and veinlets are filled by green smectites, brown smectites, and calcite, in order of abundance. No notable evolution with depth was observed.

In Hole $417 \mathrm{~A}$, the pillow margins exhibit the same concentric structure. The glass is completely palagonitized, with two types of development, according to the density of fractures in the glassy zone. Olivine phenocrysts are completely replaced by iddingsite, calcite, and green and brown smectites. Plagioclase phenocrysts are strongly altered and replaced by analcite, calcite, potash feldspar, and/or chabazite. Clinopyroxenes are not affected by alteration. Vesicles and veinlets are filled by the same minerals described in Hole 417D, in the same order of succession. Green smectites are dioctahedral and brown smectites are trioctahedral. No notable variations with depth have been noticed, except a strong oxidation in the first 10 meters of the basaltic pile.

Comparison between chemistry of fresh glasses and palagonites shows a complete depletion in $\mathrm{CaO}$; loss in $\mathrm{SiO}_{2}$, total $\mathrm{FeO}, \mathrm{MgO}, \mathrm{CaO}, \mathrm{Na}_{2} \mathrm{O}$, and $\mathrm{TiO}_{2}$; strong enrichment in $\mathrm{K}_{2} \mathrm{O}$ and $\mathrm{H}_{2} \mathrm{O}$; and a strong increase in the $\mathrm{Fe}_{2} \mathrm{O}_{3} / \mathrm{FeO}$ ratio. With these data and those available in previous studies of palagonites, the authors tried to estimate the balance of chemical exchange for the major oxides during the palagonitization process, and the average rates of chemical variation per year for each oxide. The comparison of the chemistry of fresh and altered basaltic pillow cores leads to similar conclusions concerning the behavior of major elements during alteration, but the quantities involved and rates of exchanges are quite smaller, especially for $\mathrm{CaO}$.

Rare-earth analysis of fresh and palagonitized glassy margins show a fractionation of the REE family in the palagonitic products with respect to the fresh glass, with an enrichment in light REE and a positive anomaly for cerium: these data could explain the important negative anomaly of cerium and the relative enrichment in heavy REE of sea water.
\end{abstract}




\section{DESCRIPTION OF BASALTS FROM SITE 417}

Concerning the intensity of alteration, the striking and amazing difference existing between the basalts of Hole 417A (strongly altered) and those of Hole 417D (slightly altered) is one of the main discoveries of Legs 51-52. The main macroscopic characteristics of the two basaltic sections are described for the reader's benefit.

\section{Basaltic Sequence of Hole 417A}

Hard basaltic rocks appeared at 211 meters below the sea floor and were cored until 417 meters; the total thickness cored in the basaltic layer was 206 meters. Three main rock types were recovered: (1) basaltic pillow lavas, (2) basaltic breccias, and (3) massive basaltic lavas and doleritic sills.

\section{Pillow Lavas}

They represent the dominant rock type in the section ( $\sim 72 \%$ of recovered basalts). Pillow structures are curved chilled margins with dark brown (originally) glassy rims (Plate 1, Figure 1). These curved chilled margins exfoliate in long, delicate, thin slabs of green palagonitic material, originally glassy, parallel to the chilled margin (hyaloclastites, Plate 1, Figure 1). Cracks and veinlets normal to these chilled margins converge towards a point (the geometric center of the pillow section; Plate 1, Figure 1). Pieces showing an upper and a lower chilled margin are generally 40 to $50 \mathrm{~cm}$ thick, which is a reasonable mean short axis dimension for submarine pillow lavas. In these sections, phenocryst size and groundmass grain size are higher in the middle part of the section and decrease symmetrically up and down. Vesicles tend to concentrate in the upper part of these sections.

The pillow lavas are mainly made of plagioclase-phyric basalt throughout the sequence. The percentage of plagioclase phenocrysts remains nearly constant $(\sim 10 \%)$; their size can reach $1 \mathrm{~cm}$ in the pillow center zone and decreases towards the edges. Brown-orange olivine pseudomorphs (iddingsite + calcite), up to $1 \mathrm{~cm}$ generally make up less than 5 per cent, but occur throughout the sequence with a somewhat erratic distribution. Black clinopyroxene laths, 2 to $5 \mathrm{~mm}$ long, appear from Core 30 to the bottom of the section, ranging from about 5 to 15 per cent at some levels ("three phenocrysts" basalt, from Cores 30 to 46).

The pillow margins exhibit very delicate exfoliation structures and gradual transitions to green breccias. All steps of the process can be observed; each pillow has produced several thin glassy rims during cooling. The penultimate one is often still welded to the last dark brown glassy margin (Plate 1, Figures 1, 3, and 5).

In some cases, a thin variolitic zone, 2 to $3 \mathrm{~mm}$ thick, has been observed between the brown glassy basalt and the green palagonitic outer skin. The green, thin, elongated (originally glassy) fragments exhibit a delicate "perlitic" structure, each perlitic cell delicately and concentrically zoned. The largest fragments are cemented by a matrix of smaller angular fragments of the same material; the interstitial spaces are filled with calcite, smectites, zeolites, hematite, etc.

Evidence of strong alteration is supported by the following observations.
1) The general color of the basaltic lava is gray to gray brownish, passing to yellowish orange or orange-brown along cracks, fissures, cavities, and pillow margins (over 2 to $5 \mathrm{~cm}$ ).

2) A dense net of cracks and fissures developed in the pillows, filled with calcite (white), iron hydroxydes and smectites (black-brown to orange), or smectites alone (green), sometimes with sulfides (pyrite, chalcopyrite), once with native copper. It appears that the radial cracks play an important part in the progression of the alteration towards the core of the pillows. Along these cracks, the adjacent basaltic groundmass takes a yellow brownish color, over 2 to $5 \mathrm{~cm}$ wide. Other cracks apparently stop the progression of alteration in the groundmass (see Plate 1, Figure 4). Other veinlets fillings obviously postdate the alteration of the groundmass (see Plate 1, Figure 4).

3) Phenocrysts of the basalt are deeply pseudomorphosed: plagioclase phenocrysts into white clays and zeolitic material, olivine phenocrysts into orange iddingsitecalcite and green smectites. Only clinopyroxene phenocrysts seem fresh and remain generally black and brilliant. Vesicles, not very abundant (1 to $3 \%$ ) and generally small ( $\sim 1 \mathrm{~mm}$ in diameter), are filled by the same minerals replacing the phenocrysts (mostly calcite and smectites); segregation (shrinkage) vesicles are common. Filled cavities (iron and manganese hydroxides, smectites) occur in the central part of the pillows and can reach several centimeters in diameter.

4) The glassy margins and associated interpillow hyaloclastites are completely transformed into green palagonite.

\section{Basaltic Breccias}

They represent around 20 per cent of recovered basalts and clearly have two modes of occurrence. Basaltic breccias constitute the interstitial matrix of adjacent pillow lavas (Plate 1, Figures 1 and 3), with concentric disposition of (originally) glassy fragments (now completely transformed into green palagonite) around the margins of the pillows. They also form breccia horizons separating pillow lava flow units (Plate 1, Figure 2). In both cases, we assume that we are dealing with true hyaloclastic breccias, made of the following;

1) A majority of small green, or green and brown (originally glassy) fragments of "perlitic" material, with delicate concentric zoning (see Plate 1, Figure 2), and elongated or spheroidal shapes;

2) Dark brown basaltic pillow fragments, with both angular and rounded shapes (Plate 1, Figure 2);

3) A fine-grained matrix of angular green fragments $(0.5$ to $2 \mathrm{~mm}$ ) cemented by calcite, hematite, smectites, etc.

The two dominant colors of these breccias, green and dark brown, outline the deep state of alteration reached in these porous and granulated formations.

\section{Massive Basalts and Dolerites}

They represent around 8 per cent of recovered hard rocks. Sub-units 17A and 18A consist of "three phenocrysts", phyric basalt similar to that of Unit 16 , but devoid of vesicles. Sub-unit 18B is a fresh crystalline ophitic gray dolerite, with gray transparent plagioclase and black augitic pyroxene, also devoid of vesicles. 


\section{Basaltic Sequence of Hole 417D}

Hard basaltic rocks appeared at 343 meters below the sea floor and were cored until 532 meters during Leg 51 (189 m cored), and from 532 to 708.5 meters during Leg 52 (176.5 $\mathrm{m}$ cored). The total thickness cored in the basaltic layer is 365.5 meters ( $264 \mathrm{~m}$ recovered). The main rock types recovered are basaltic pillow lavas, basaltic breccias, massive dolerites, and limestone sediments. The left part of Table 1 outlines the lithological units distinguished in the whole sequence.

\section{Pillow Lavas}

They represent, as in Hole 417A, the dominant rock type in the section (Plate 2, Figures 1 to 4).

Evidence for pillow structures is exactly the same as in Hole 417A. They are mainly made of plagioclase phyric basalt, with generally 10 to 15 per cent fresh (or slightly altered) brilliant plagioclase phenocrysts, 2 to $5 \mathrm{~mm}$ long (up to $10 \mathrm{~mm}$ in pillow cores). Olivine pseudomorphs (smectites, calcite, iddingsite) always accompany the plagioclase phenocrysts ( $<2$ to $3 \%, 2$ to $5 \mathrm{~mm}$ long). Black and brilliant clinopyroxene phenocrysts progressively increase in proportion when going downhole (from 0 to $\sim 3 \%$ ). The groundmass is dark gray, typical of fresh basalt, except along veinlets and cracks, and in the fine-grained chilled zones, where it turns to brownish gray over 0.5 to 2 $\mathrm{cm}$. Vesicles are scarce and small $(<1 \%,<1 \mathrm{~mm}$ diameter) and are filled with calcite and smectites. Segregation (shrinkage) vesicles are common (Plate 2, Figure 6). Filled cavities, in the cores of pillows, can reach several centimeters in length. Veinlets and cracks are filled with calcite, smectites, hematite, or minor sulfides.

Glassy margins, in contrast with margins of Hole 417A, are made of fresh glass, black and brilliant, with a constant thickness of $10 \mathrm{~mm}$ in the upper margins, and 5 to $8 \mathrm{~mm}$ in the lower margins. All the delicate exfoliation structures (Plate 2, Figures 3 and 4 ) and gradual transitions to hyaloclastic breccias described in Hole 417A are visible, including the transitional variolitic zone.

The glassy fragments in the hyaloclastic matrix around the pillows exhibit a delicate "perlitic" structure. Plagioclase phenocrysts in the glassy margin or close to it contain a great number of fresh glassy inclusions (see Clocchiatti, this volume).

In summary, although the pillow structures in both holes are the same, even in the finest details, the material is quite different because we are dealing here with fresh black glass, not with the green palagonitic material found in Hole 417A.

Devitrification products (palagonite) appear, however, and increase in proportion with depth, selectively developed in brecciated glassy margins and in hyaloclastic breccias. Persistence of fresh glass in many selvedges throughout the entire section is one of the most amazing facts concerning this hole. The degree of alteration of these 110-m.y.-old basalts is actually quite identical to that of a young 6- to 10-m.y.-old basalts cored during Legs 45 and 46 .

\section{Basaltic Breccias}

They represent probably less than 10 per cent of recovered basalts and occur mainly as interstitial matrix of adjacent pillows, with concentric disposition of the glassy fragments around the margins of the pillows. True interflow breccia horizons, so frequent in Hole $417 \mathrm{~A}$, are rare to nonexistent in the first half of the section and begin to develop in the second half (Sub-units 9B and 9C, Unit 11, etc.).

\section{Massive Dolerites}

Eight units of massive lavas with doleritic aspect have been found in Hole 417D (see left part of Table 1). These massive basalts represent roughly around one-third of the cored section (versus $8 \%$ in Hole 417A). The shipboard scientists of Leg 51 favored an intrusive origin (sills); the scientists of Leg 52 favored an extrusive origin (flows) for these massive lavas. In any case, they are made of the freshest lavas of the whole section.

\section{Limestones}

Coarse-grained calcite is the usual cement of the hyaloclastic breccias, but a true fine-grained pelagic limestone sediment often replaces the hyaloclastic breccias filling the voids between pillows. They show ghosty outlines of fossils (radiolarians) and in two occurrences seem to be interbedded between pillow lava flows.

In summary, the macroscopic observation of the two basaltic sections leads to the following conclusions:

a) The two basaltic sections are made of the same "three phenocrysts" phyric basalt.

b) The pillow breccias are more abundant in Hole 417A.

c) Limestone sediments and calcite cement are much more developed in Hole 417D.

d) There is a strong contrast concerning the degree of alteration. Basalts of Hole 417A are strongly altered (phenocrysts as well as groundmass) and completely devitrified; basalts of Hole 417D are only slightly altered (except at some particular levels) and only devitrified.

Among the factors that can explain this difference, we want to emphasize the abundance of carbonates in the interpillow voids of Hole 417D, which could be responsible for the surprisingly good preservation of fresh black and brilliant glass in the pillow margins.

\section{MINERALOGY OF ALTERATION IN BASALTS FROM SITE 417}

\section{Moderate Alteration in Samples From Hole 417D}

The pillow lavas of Hole 417D exhibit a systematic concentric structure with four main zones, from margin to core (Figure 1).

A glassy zone (GZ), $5 \mathrm{~mm}$ thick, is made of a pale yellow isotropic glass, containing scattered olivine and plagioclase microlites ( 30 to $50 \mu \mathrm{m}$ ). The average refraction index of the fresh glass, measured by immersion, is 1.602 and its average density is 2.78 .

A variolitic zone (VZ), $1 \mathrm{~cm}$ thick, is made of small ellipsoidal varioles (50 to $100 \mu \mathrm{m}$ ) isolated in the fresh glass. The varioles are generally centered around a microlite or microphenocryst of plagioclase (An 50 to 75), which is surrounded by a thin rim of fibrous, brown, and anisotropic minerals; after Baragar et al. (1977), these tiny rims would be made of plagioclase and pyroxene. 
TABLE

Secondary Mineralogy in Hole 417D

\begin{tabular}{|c|c|c|c|c|c|c|c|c|c|c|}
\hline \multirow{2}{*}{$\begin{array}{l}\text { Lithologic } \\
\text { Units }\end{array}$} & \multirow{2}{*}{$\begin{array}{c}\text { Sample } \\
\text { (Interval in } \mathrm{cm} \text { ) }\end{array}$} & \multirow{2}{*}{$\begin{array}{l}\text { Sub-Bottom } \\
\text { Depth } \\
(\mathrm{m})\end{array}$} & \multirow[b]{2}{*}{ (1) } & \multirow[b]{2}{*}{ (2) } & \multicolumn{3}{|c|}{ Veins, Vesicles } & \multirow[b]{2}{*}{ (3) } & \multirow[b]{2}{*}{ (4) } & \multirow[b]{2}{*}{ (5) } \\
\hline & & & & & $\mathrm{Cc}$ & $\mathrm{BC}$ & GP & & & \\
\hline $1 \mathrm{a}$ & $\begin{array}{l}26-3,74-78 \\
26-4,132-135 \\
27-1,82-86\end{array}$ & $\begin{array}{l}361.2 \\
363.3 \\
367.4\end{array}$ & $\begin{array}{l}\mathrm{PC} \\
\mathrm{H} \\
\mathrm{GM}\end{array}$ & & + & + & $\begin{array}{l}+ \\
+\end{array}$ & & + & \\
\hline $1 \mathrm{~b}$ & $\begin{array}{l}27-2,3-7 \\
27-3,11-15 \\
27-4,52-57 \\
27-4,77-82 \\
27-5,16-19 \\
27-7,29-33 \\
28-3,60-65 \\
28-5,143-146\end{array}$ & $\begin{array}{l}368.1 \\
369.6 \\
371.4 \\
371.6 \\
372.5 \\
375.4 \\
379.0 \\
382.5\end{array}$ & $\begin{array}{l}\text { GM } \\
\text { PC } \\
\text { GM } \\
\text { H } \\
\text { PC } \\
\text { GM } \\
\text { H } \\
\text { GM }\end{array}$ & & $\begin{array}{l}+ \\
+ \\
+ \\
+ \\
+\end{array}$ & $\begin{array}{l}+ \\
+ \\
+ \\
+\end{array}$ & $\begin{array}{l}+ \\
+\end{array}$ & $\begin{array}{l}+ \\
+ \\
+ \\
+\end{array}$ & $\begin{array}{l}+ \\
+\end{array}$ & $\begin{array}{l}+ \\
+\end{array}$ \\
\hline $1 \mathrm{c}$ & $\begin{array}{l}29-3,67-72 \\
29-4,3-7 \\
29-4,125-128 \\
30-2,43-45 \\
30-3,128-132 \\
30-6,15-20 \\
30-7,114-119 \\
30-8,81-85 \\
31-1,94-96 \\
31-3,144-148\end{array}$ & $\begin{array}{l}388.1 \\
388.9 \\
390.0 \\
395.0 \\
397.3 \\
399.9 \\
401.9 \\
402.5 \\
403.9 \\
407.4\end{array}$ & $\begin{array}{l}\mathrm{H} \\
\mathrm{H} \\
\mathrm{H} \\
\mathrm{PC} \\
\mathrm{H} \\
\mathrm{H} \\
\mathrm{GM} \\
\mathrm{H} \\
\mathrm{PC} \\
\mathrm{GM}\end{array}$ & & $\begin{array}{l}+ \\
+\end{array}$ & $\begin{array}{l}+ \\
+\end{array}$ & + & $\begin{array}{l}+ \\
+ \\
+\end{array}$ & $\begin{array}{l}+ \\
+ \\
+\end{array}$ & $\begin{array}{l}+ \\
\\
\\
+ \\
+\end{array}$ \\
\hline 2 & $32-1,34-39$ & 412.4 & PC & + & + & + & & & & \\
\hline 3 & $34-3,55-58$ & 432.4 & MB & & + & + & & & & \\
\hline 4. & $\begin{array}{l}35-1,136-140 \\
36-4,23-26 \\
37-1,43-47 \\
38-1,78-82 \\
39-1,11-14 \\
39-2,15-21 \\
39-3,12-18 \\
40-2,110-112 \\
41-1,114-118 \\
41-3,42-48 \\
41-5,110-115 \\
41-5,141-147 \\
42-1,114-118 \\
42-3,100-105\end{array}$ & $\begin{array}{l}438.9 \\
449.4 \\
451.3 \\
458.9 \\
464.8 \\
466.0 \\
467.1 \\
473.6 \\
476.6 \\
478.5 \\
481.6 \\
481.9 \\
485.8 \\
488.6\end{array}$ & $\begin{array}{l}\text { GM } \\
\text { GM } \\
\text { GM } \\
\text { GM } \\
\text { GM } \\
\text { GM } \\
\text { MB } \\
\text { GM } \\
\text { GM } \\
\text { GM } \\
\text { MB } \\
\text { GM } \\
\text { MB } \\
\text { MB }\end{array}$ & $\begin{array}{l}+ \\
+\end{array}$ & $\begin{array}{l}+ \\
+ \\
+\end{array}$ & $\begin{array}{l}+ \\
+ \\
+ \\
+ \\
+ \\
+ \\
+ \\
+ \\
+\end{array}$ & $\begin{array}{l}+ \\
+ \\
+ \\
+ \\
+ \\
+ \\
+ \\
+ \\
+ \\
+\end{array}$ & $\begin{array}{l}+ \\
+\end{array}$ & $\begin{array}{l}+ \\
+\end{array}$ & $\begin{array}{l}+ \\
+ \\
+ \\
+ \\
+ \\
+\end{array}$ \\
\hline 5 & $\begin{array}{l}42-4,72-77 \\
42-4,127-132\end{array}$ & $\begin{array}{l}489.8 \\
490.4\end{array}$ & $\begin{array}{l}\mathrm{MB} \\
\mathrm{PC}\end{array}$ & & $\begin{array}{l}+ \\
+\end{array}$ & $\begin{array}{l}+ \\
+\end{array}$ & & & & + \\
\hline 6 & $43-5,35-38$ & 499.7 & MB & & + & + & + & & & + \\
\hline 7 & $\begin{array}{l}43-6,77-82 \\
44-2,68-71 \\
44-4,131-133\end{array}$ & $\begin{array}{l}501.5 \\
501.1 \\
508.7\end{array}$ & $\begin{array}{l}\mathrm{PC} \\
\mathrm{H} \\
\mathrm{PC}\end{array}$ & & $\begin{array}{l}+ \\
+ \\
+\end{array}$ & $\begin{array}{l}+ \\
+\end{array}$ & + & & & $\begin{array}{l}+ \\
+ \\
+\end{array}$ \\
\hline 8 & $\begin{array}{l}49-1,51-53 \\
49-3,12-14\end{array}$ & $\begin{array}{l}539.5 \\
542.1\end{array}$ & $\begin{array}{l}\text { MB } \\
\text { MB }\end{array}$ & & $\begin{array}{l}+ \\
+\end{array}$ & & & & & $\begin{array}{l}+ \\
+\end{array}$ \\
\hline $9 \mathrm{a}$ & $\begin{array}{l}52-6,35-38 \\
54-1,2-5 \\
58-1,102-106\end{array}$ & $\begin{array}{l}565.5 \\
577.0 \\
618.0\end{array}$ & $\begin{array}{l}\text { MB } \\
\text { GM } \\
\text { GM }\end{array}$ & & $\begin{array}{l}+ \\
+\end{array}$ & $\begin{array}{l}+ \\
+\end{array}$ & & & + & $\begin{array}{l}+ \\
+ \\
+\end{array}$ \\
\hline $\begin{array}{l}9 \mathrm{~b}, \mathrm{c} \\
9 \mathrm{~d}\end{array}$ & $62-1,67-71$ & 642.6 & $\mathrm{MB}$ & & + & & & & & + \\
\hline 10 & & & & & & & & & & \\
\hline 11 & $66-5,32-36$ & 684.3 & GM & & & + & & & + & + \\
\hline 12 & $\begin{array}{l}67-4,40-43 \\
67-4,77-80\end{array}$ & $\begin{array}{l}691.4 \\
691.7\end{array}$ & $\begin{array}{l}\text { MB } \\
\text { MB }\end{array}$ & & $\begin{array}{l}+ \\
+\end{array}$ & & & & & $\begin{array}{l}+ \\
+\end{array}$ \\
\hline 13 & $67-6,30-33$ & 694.0 & $\mathrm{PC}$ & & + & & & & & + \\
\hline
\end{tabular}

Note: Recomputed depth value. Column $1=$ nature of the samples, $\mathrm{H}=$ hyaloclastic breccias, $\mathrm{GM}=$ glassy margins, $\mathrm{PC}=$ cores of pillows, $\mathrm{MB}=$ massive basalts $;$ Column 2 = plagioclase phenocrysts transformed to brownish smectites; veins and veinlets: $\mathrm{Cc}=$ calcite, $\mathrm{BC}=$ brown clays, $\mathrm{GP}=$ green phyllites; Column $3=$ calcitic matrix with phillipsite; Column $4=$ matrix of phillipsite; Column $5=$ iron oxides. 


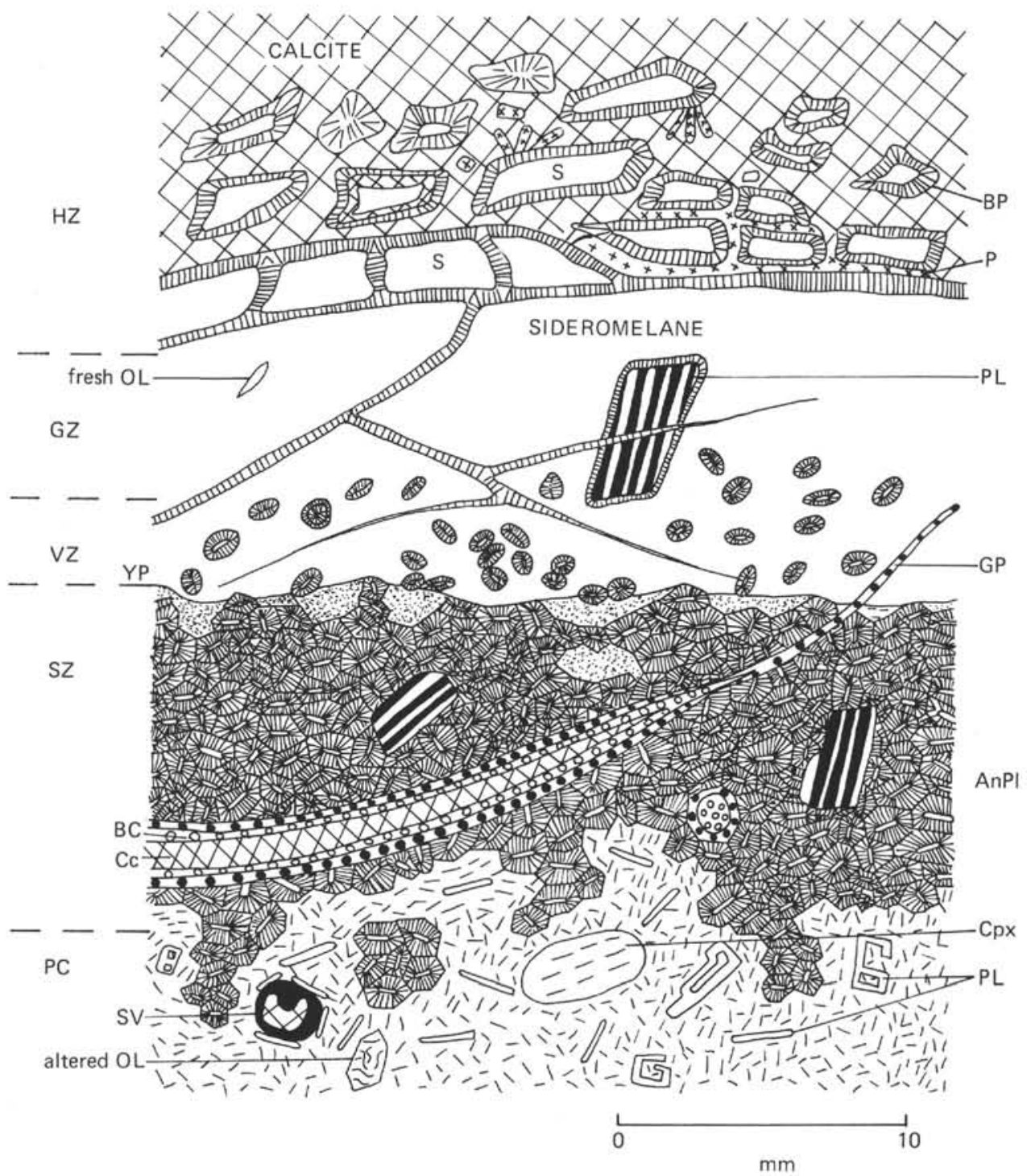

Figure 1. Synthetic section of a pillow lava margin, Hole 417D, showing a typical concentric structure. $H Z=$ hyaloclastic zone, made of glassy fragments (sideromelane $S$, with brown fibrous palagonitic margins $B P$ ), and a calcitic matrix, with scarce phillipsite $(P) . G Z=$ glassy zone, with fresh plagioclase $(P L)$ and olivine $(O L)$ phenocrysts. $V Z=$ variolitic zone, with isolated varioles in fresh sideromelane. $S Z=$ spherulitic zone, where varioles coalesce, with scarce analcitized plagioclases (An Pl) and olivine phenocrysts; isolated glassy areas are transformed to yellow palagonite (YP). $P C=$ pillow core, microlitic texture, with hollow plagioclase microlites $(P L)$ and plumose clinopyroxene intergrowths, transformed plagioclase and olivine $(O L)$ phenocrysts, fresh CPX phenocrysts, often rounded (Cpx), and segregation vesicles $(S V)$. Veinlets are filled with green $(G P)$ and brown smectites $(B C)$ and calcite $(C c)$.

In the spherulitic zone (SZ), $1 \mathrm{~cm}$ thick, the varioles join together, forming a polygonal net. Scattered glassy areas remain between the spherulites, which are completely transformed to a pale yellow microcrystalline product. Plagioclase, olivine, and scarce augite (often rounded) phenocrysts are more abundant than in the variolitic zone; they also are surrounded by a thin fibrous rim.
The pillow core (PC) begins where spherulites grade to an arborescent texture of hollow plagioclase microlites associated with plumose pyroxene intergrowth, indicating a fast cooling (Bryan, 1972). Segregation vesicles are restricted to this zone, and pyroxene phenocrysts are more abundant.

This concentric zoning of the pillow lavas has already been described in samples from Leg 37 (Baragar et al., 
1977), and observed by the authors in samples from Leg 46 (Lofgren, 1971). It is a primary structure indicating fast cooling conditions. Part of the outer glassy zone can be brecciated with formation of friction hyaloclastic breccias (HZ) cemented mainly by calcite, and by minor phillipsite.

The moderate alteration in the pillow lavas appears at the margin of the hyaloclastic glassy fragments (HZ), progressing along microcracks in the glassy zone $(\mathrm{GZ})$, in the phenocrysts and mesostasis of the pillow core (PC), and in the vesicles and veinlets.

\section{Alteration of the Glass}

Two kinds of palagonite appear in the pillow-lavas: a yellow palagonite developed in the variolitic zone, and a brown palagonite forming delicate concentric rims at the margins of the glassy fragments in the hyaloclastic breccias. The glassy zone itself remains fresh, except along cracks (brown palagonite).

The yellow palagonite appears in isolated glassy areas inside the variolitic zone, or between the $\mathrm{VZ}$ and spherulitic zone. It has a rather high birefringence and a fibrous aspect (fibropalagonite). Microprobe analysis made by Mevel (this volume) in this fibropalagonite shows higher contents in $\mathrm{K}_{2} \mathrm{O}, \mathrm{H}_{2} \mathrm{O}$, and total $\mathrm{FeO}$, and lower contents in $\mathrm{SiO}_{2}$, $\mathrm{MgO}$, and $\mathrm{CaO}$, than in the brown palagonite. This difference could reflect the chemical difference in the composition of the initial glass in the two zones (Bass, 1976).

The brown and green-brownish palagonite develops as thin concentric rims around hyaloclastic fragments. The rims are alternatively made of green to brown fibrous smectites, isodiametral microcrystalline smectites, iron oxides, calcite (rare), sub-isotropic pale yellow to green homogeneous products. Figure 2 shows the different types of organization observed: Types A, B, C, and D are observed in the most external fragments, completely altered (no relicts of fresh glass); Types E and F characterize fragments closer to the glassy zone and containing fresh glass in their center zone. These palagonitized margins are more complex and thicker, with a greater number of layers, than those observed in the younger Leg 45 samples.

$\mathrm{X}$-ray diffraction patterns, obtained for 16 samples of the brown palagonite extracted from the hyaloclastic breccias, indicate a smectite of the dioctahedral type (montmorillonite) until a depth of 475 meters, and a trioctahedral smectite (saponite type) in the deeper samples studied (Table 2). Four microprobe analyses of these palagonites made by Mevel (this volume) are in good agreement with our diffractometric data: the four palagonites have smectites compositions and the deepest one (the only one deeper than $475 \mathrm{~m}$ ) has notably higher $\mathrm{MgO}$ and $\mathrm{FeO}$ contents, with lower $\mathrm{Al}_{2} \mathrm{O}_{3}$.

Chemical profiles obtained by SEM (Cameca 07) on the margins of some hyaloclastic fragments (Types B and F, Figure 2) indicate large chemical variations between adjacent palagonitic layers (Figure 3). In spite of these variations, some overall tendencies appear from the inner layers to the outer ones: moderate loss in $\mathrm{Na}, \mathrm{Ca}$, and $\mathrm{Ti}$; strong enrichment in $\mathrm{K}$, moderate in $\mathrm{Fe}$; and irregular behavior of $\mathrm{Si}, \mathrm{Al}$, and $\mathrm{Mg}$. Enrichment in $\mathrm{K}$ and $\mathrm{Fe}$ in the outer layers is noteworthy, suggesting that the smectites of these outer layers could be close to what has been called a "protoceladonite."
In the fresh glassy zone (GZ) palagonite develops only along cracks. Figure 4 shows the evolution and generation of successive layers along one of these cracks. Alteration begins by small gray anistropic microcrystalline spots at the beginning of the crack (Stage I). These spots join together and form a first layer along the crack (Stage II). As the first layer begins to recrystallize (brownish granular microcrystals), a new layer appears at the expense of the sideromelane S (Stage III). Transformations then appear in the first layer, which differentiates into thin fibrous, granular, or ironoxide layers (Stages IV and V). At the end of Stage V, the second layer begins to differentiate in the same way, and a third layer forms at the expense of the fresh glass (Stage VI), etc. The final product is a layered altered zone parallel to the original crack, where fibrous palagonite and iron oxides predominate in the central zone.

Chemical profiles across this crack obtained by SEM show an evolution of major elements quite similar to that of the hyaloclastic fragments (Figure 5). From the fresh glass, $\mathrm{S}$, to the outermost layers adjacent to the crack, there is an enrichment in $\mathrm{K}$ and loss in $\mathrm{Mg}, \mathrm{Ca}$, and $\mathrm{Fe}$; enrichment in $\mathrm{K}$ is observed since the first stage of alteration.

\section{Alteration of the Phenocrysts}

Clinopyroxene is never altered. Plagioclase phenocrysts are generally devoid of alteration, except in some samples, where they are partly replaced by a brownish dioctahedral montmorillonite (see Table 1). Some plagioclases are partly replaced by calcite in the immediate vicinity of calcite veinlets. Olivine phenocrysts as usual are completely replaced either by calcite and iron oxides, or by brown to green smectites and iron oxides (Figure 6A, 6C). Fresh olivine microphenocrysts have been seen in the fresh glassy margins of the pillow lavas; this is a further indication that water did not enter the fresh glass of the glassy zone (GZ).

\section{Alteration of the Mesostasis}

The mesostasis in the core of the pillows is made of fresh hollow plagioclase microlites and belt buckle-shaped or plumose clinopyroxenes, cemented by interstitial glass altered to brownish smectite and iron oxides. Brown reddish iron oxides concentrate along the cracks and fissures.

\section{Vesicles and Veinlets in the Pillow Cores}

Vesicles and veinlets exhibit the same filling products, mainly brown clays, green clays, and calcite. X-ray diffraction patterns show that the brown clays are trioctahedral and the green clays are dioctahedral smectites. Qualitative analysis by SEM show that the latter are richer in $\mathrm{K}$ and $\mathrm{Fe}$, in agreement with microprobe analysis made by Mevel (this volume), suggesting a "protoceladonite" composition (the $10 \AA$ peaks of the mica group never appear on the diffractograms).

Figure 7A, 7B, 7F show different stages of evolution of the filling of veinlets: the green smectite (protoceladonite?) is always the first to crystallize as fibers normal to the wall of the crack, followed by fine granular microcrystals of the same green smectite (Figure 7A), then again by the fibrous variety (Figure 7B), and finally by a brownish dioctahedral smectite (Figure 7F). If calcite participate to the filling, it is always the last mineral to crystallize, as in Figure 7G. 
A

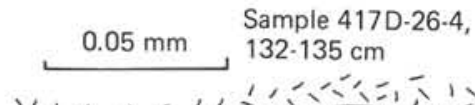

C
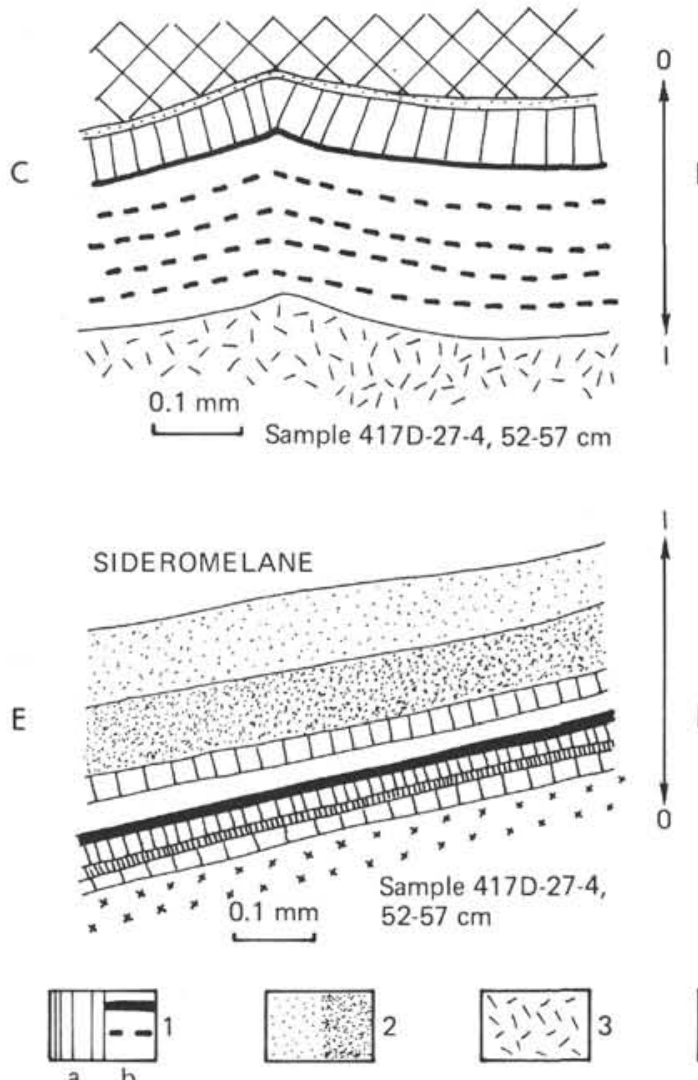

$0.1 \mathrm{~mm}$

Sample 417D-28-4, 2-8 cm
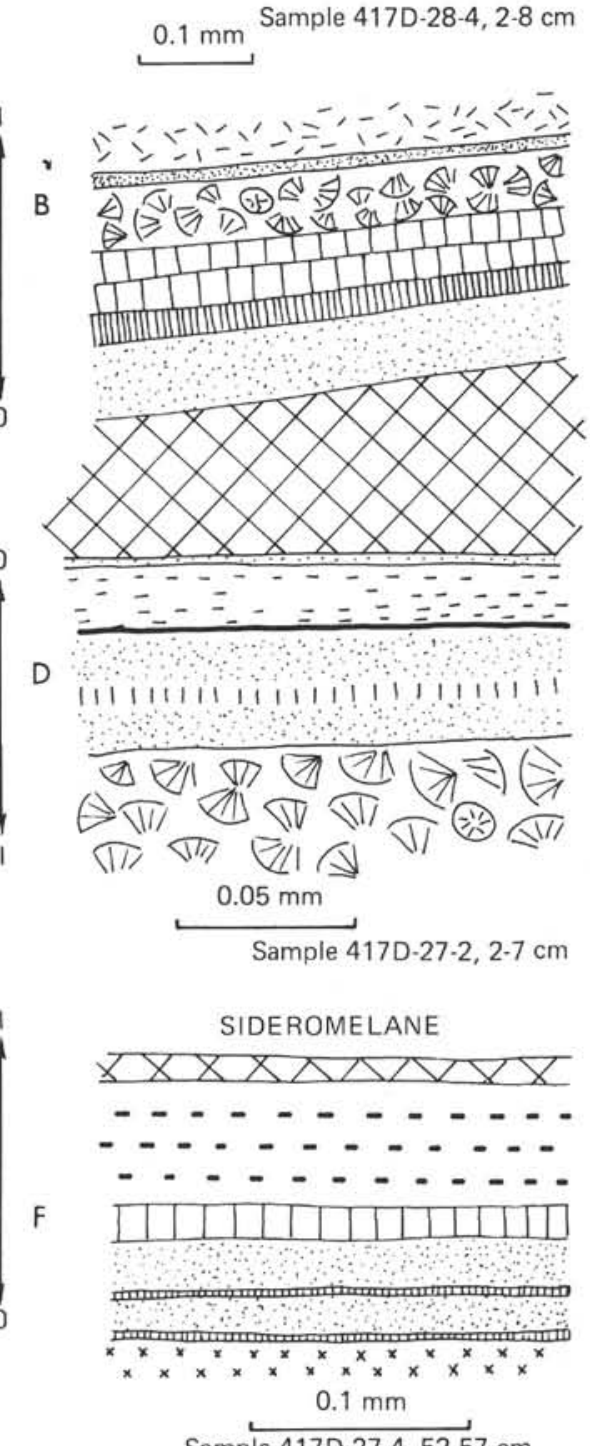

$--------$
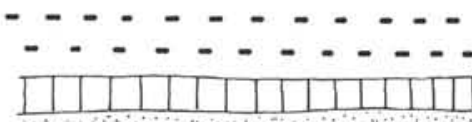

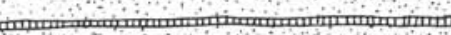

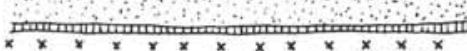

$x^{x} x^{x} x^{x} x^{x} x^{x} x^{x} x^{x} x^{x} x^{x} x^{x} x^{x}$

$0.1 \mathrm{~mm}$

Sample 417D-27-4, 52-57 cm
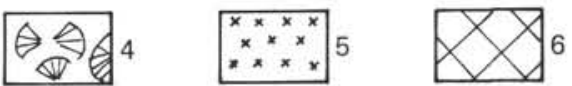

$1 \mathrm{a}=$ Fibrous minerals $1 \mathrm{~b}=$ Opaque minerals $2=$ Granular minerals

$3=$ Brown, fibrous phyllites $4=$ Gray, fan-shaped phyllites

5 = Phillipsite 6 = Calcite $1=$ inside $O=$ outside

Figure 2. Different types of marginal rims in hyaloclastic elements, Hole 417D.

The segregation vesicles are generally filled with calcite (as in Figure 7D) and sometimes with more complex concentric layers showing exactly the same order of crystallization than in the veinlets: green smectite ("protoceladonite'"?), brownish dioctahedral smectite, and calcite, as in Figure 7C, 7E.

\section{Variation of Alteration With Depth}

Table 1 gives the list of analyzed samples, their depth, nature, and secondary mineralogy. No notable evolution with depth was observed.

\section{Strong Alteration Samples From Hole 417A}

The pillow lavas of Hole 417A (see Figure 8) exhibit the same concentric structure as in Hole 417D, i.e., a hyaloclastic zone, a palagonitized glassy zone, a variolitic zone, a spherulitic zone, and a pillow core.

\section{Alteration of the Glass}

The glass in Hole 417A is completely palagonitized, except in two or three samples where relicts of fresh glass have been mentioned in the DSDP Initial Core Descriptions. 
TABLE 2

X-Ray Diffraction Data for "Palagonite" in Leg 51 Samples

\begin{tabular}{|c|c|c|c|c|c|c|c|}
\hline $\begin{array}{c}\text { Sample } \\
\text { (Interval in cm) }\end{array}$ & $d(001)$ & $d(110)$ & $d(200)$ & $d(060)$ & Matrix & & Type \\
\hline \multicolumn{8}{|l|}{ Hole 417A } \\
\hline $24-1,133-138$ & 12.5 & 4.47 & 2.58 & 1.498 & - & & Di \\
\hline $24-2,65-67$ & 14.3 & 4.46 & 2.57 & 1.501 & + & & Di \\
\hline $24-3,40-44$ & 12.2 & 4.50 & 2.57 & 1.501 & - & & Di \\
\hline $26-1,96-101$ & 14.5 & 4.52 & 2.53 & 1.512 & + & & Di \\
\hline $26-4,95-97$ & 12.4 & 4.44 & 2.56 & 1.500 & 。 & & Di \\
\hline $26-5,67-69$ & 12.5 & 4.52 & 2.58 & 1.504 & o & & Di \\
\hline $29-4,24-27$ & & 4.50 & 2.58 & 1.506 & & + & Di \\
\hline $30-1,32-37$ & 12.3 & 4.44 & 2.56 & 1.509 & o & & Di \\
\hline $30-1,45-47$ & 13.5 & 4.51 & 2.59 & 1.504 & $\circ$ & & Di \\
\hline $30-2,60-68$ & 12.0 & 4.50 & 2.57 & 1.510 & - & & Di \\
\hline $31-2,39-42$ & 12.5 & 4.52 & 2.59 & 1.506 & - & & Di \\
\hline $32-1,118-121$ & 14.5 & 4.50 & 2.58 & 1.509 & & $H$ & Di \\
\hline $32-2,28-31$ & 14.5 & 4.48 & 2.57 & 1.506 & & + & Di \\
\hline $32-4,66-69$ & & 4.52 & 2.58 & 1.511 & + & & Di \\
\hline $32-5,77-82$ & 12.3 & 4.46 & 2.57 & 1.509 & $\circ$ & & Di \\
\hline $34-1,127-129$ & & 4.48 & 2.57 & 1.510 & o & & Di \\
\hline $35-5,2-6$ & 13.4 & 4.50 & 2.58 & 1.510 & & + & $\mathrm{Di}$ \\
\hline $42-3,123-128$ & 14.5 & 4.52 & 2.58 & 1.511 & + & & $\mathrm{Di}$ \\
\hline \multicolumn{8}{|l|}{ Hole 417D } \\
\hline $27-4,77-82$ & 15.0 & 4.50 & 2.60 & 1.504 & + & & $\mathrm{Di}$ \\
\hline $27-7,29-33$ & 14.4 & 4.48 & 2.57 & 1.513 & + & & $\mathrm{Di}$ \\
\hline $30-3,128-132$ & 14.5 & 4.48 & 2.57 & 1.512 & + & & Di \\
\hline $30-6,15-20$ & 14.5 & 4.46 & 2.59 & 1.504 & & $H$ & Di \\
\hline $30-7,114-117$ & 15.0 & 4.47 & 2.57 & 1.502 & + & & $\mathrm{Di}$ \\
\hline $32-1,34-39$ & 12.0 & 4.42 & & 1.502 & 。 & & Di \\
\hline $35-1,136-140$ & 14.5 & 4.38 & & 1.502 & + & + & Di \\
\hline $38-1,78-82$ & 15.0 & 4.42 & 2.57 & 1.513 & + & & $\mathrm{Di}$ \\
\hline $39-1,11-14$ & 14.7 & 4.46 & 2.56 & 1.500 & & ++ & Di \\
\hline $40-2,110-112$ & 14.5 & 4.44 & & 1.510 & + & & $\mathrm{Di}$ \\
\hline $41-1,114-118$ & 12.3 & 4.54 & 2.59 & 1.527 & - & & Tri \\
\hline $41-3,42-48$ & 13.0 & 4.48 & 2.54 & 1.522 & & & Tri \\
\hline $42-1,70-72$ & 12.1 & 4.50 & 2.53 & 1.531 & $\circ$ & & Tri \\
\hline $44-2,68-71$ & 12.1 & 4.48 & & 1.527 & o & & Tri \\
\hline $54-2,60-62$ & 12.1 & 4.50 & & 1.534 & o & & Tri \\
\hline $66-5,32-36$ & 14.2 & 4.50 & 2.55 & 1.517 & & + & Tri \\
\hline
\end{tabular}

Note: $+=$ calcite matrix with phillipsite crystals $++=$ phillipsite matrix ${ }^{\circ}=$ calcite matrix $\mathrm{Di}=$ dioctahedral smectite $\mathrm{Tri}=$ trioctahedral smectite.

In the variolitic zone, interstitial glass has crystallized, forming large radiating brownish smectites around the varioles, and microcrystalline granular brownish smectites in the remaining spaces (Figure 9).

In the glassy margins of the pillow lavas, the alteration pattern is controlled by the state of fracturation of the pillow margin (Figure 8). If the margin is not (or poorly) fractured, concentric rims of alteration products develop around phenocrysts and microlites (Figure 8 , left). Phenocrysts are surrounded first by large smectite fibers $(0.1 \mathrm{~mm})$, then by numerous thin rims of microcrystalline clays alternating with iron oxide/hydroxide rims. Microlites are surrounded by the same kinds of rims, but with smaller smectite fibers $(0.01 \mathrm{~mm})$. In the remaining spaces, beyond the concentric rims, the glass is devitrified to microcrystalline clays (Figure 10). If the glassy margin is highly fractured (Figure 8 , right; Figure 11), the fractures outline polygonal spaces, 0.2 to $5 \mathrm{~mm}$ wide, where concentric clay rims develop parallel to the fractures. The rims are alternatively fibrous and microcrystalline, with iron oxides appearing as thin layers towards the center. In the center, disordered or radiating microcrystalline clays are associated with small iron oxides. Figure 11 shows that in this case the progress of palagonitization is controlled by the fractures pattern, and not by the distribution of the phenocrysts or microlites as in
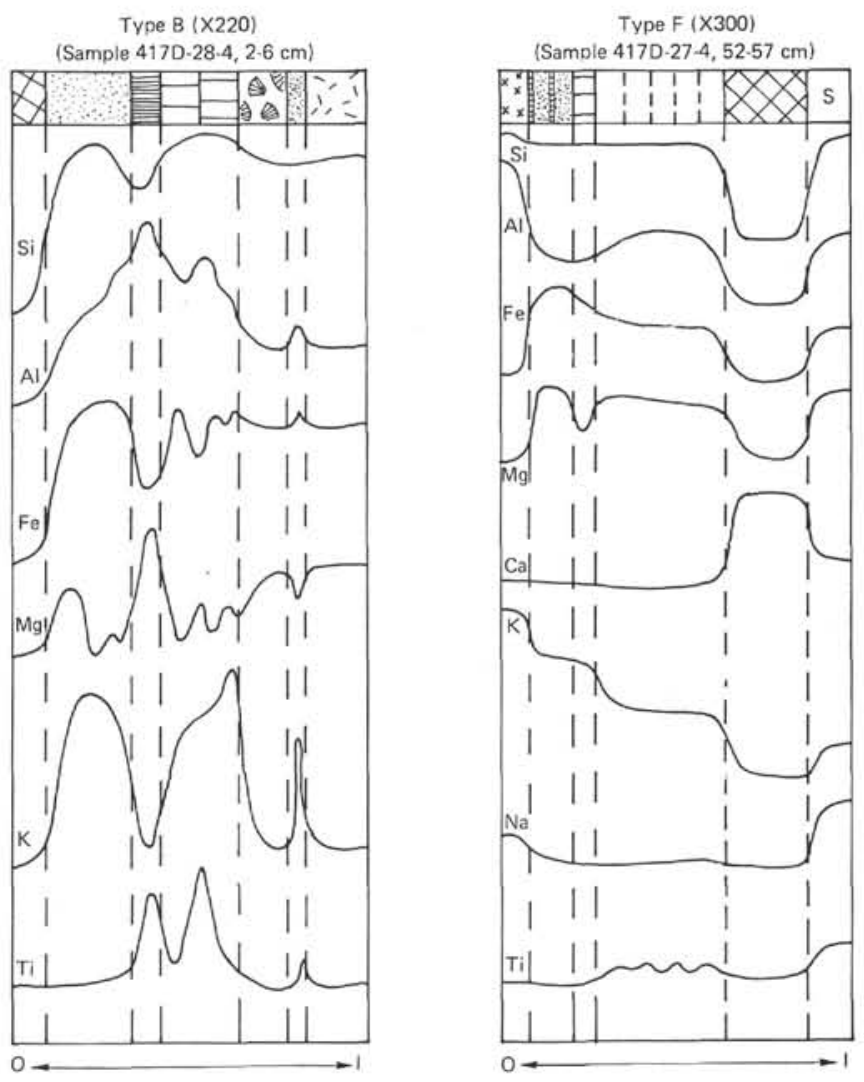

Figure 3. Electron scanning profiles across alteration rims in hyaloclastic elements, Hole 417D. For graphic symbols, see Figure 2.

the previous case. The most external parts of the glassy zone are strongly oxidized with development of brown reddish iron hydroxides masking the delicate palagonite rims.

In the hyaloclastites, the alteration of the glassy fragments reflects their origin from a poorly or highly fractured glassy margin (Figure 8). They are always entirely palagonitized to green and brown smectites, forming delicate rims parallel to their margins (Plate 1, Figure 7). Fractions of these smectites smaller than $2 \mu \mathrm{m}$ have been separated and analyzed by X-ray diffraction: the patterns obtained are those of a dioctahedral montmorillonite-like smectite (Table 2).

\section{Alteration of Phenocrysts}

Olivine phenocrysts are completely replaced by iddingsite in the strongly oxidized zones, especially at the top of the basaltic pile (first $10 \mathrm{~m}$ ), or by calcite and green to brown smectites (Figure 6B).

Plagioclase phenocrysts are partially or completely replaced by a dioctahedral pinkish clay (Plate 1, Figure 6), alone or associated with analcite, calcite, potash feldspar, or chabazite (Figure 6D, 6E, 6F). All these minerals have been determined by X-ray diffraction (see Table 3 ) and confirmed by microprobe analysis made by Mevel (this volume). Two, three, or four of these phases can co-exist in a single plagioclase phenocryst; clear evidence of an order of 


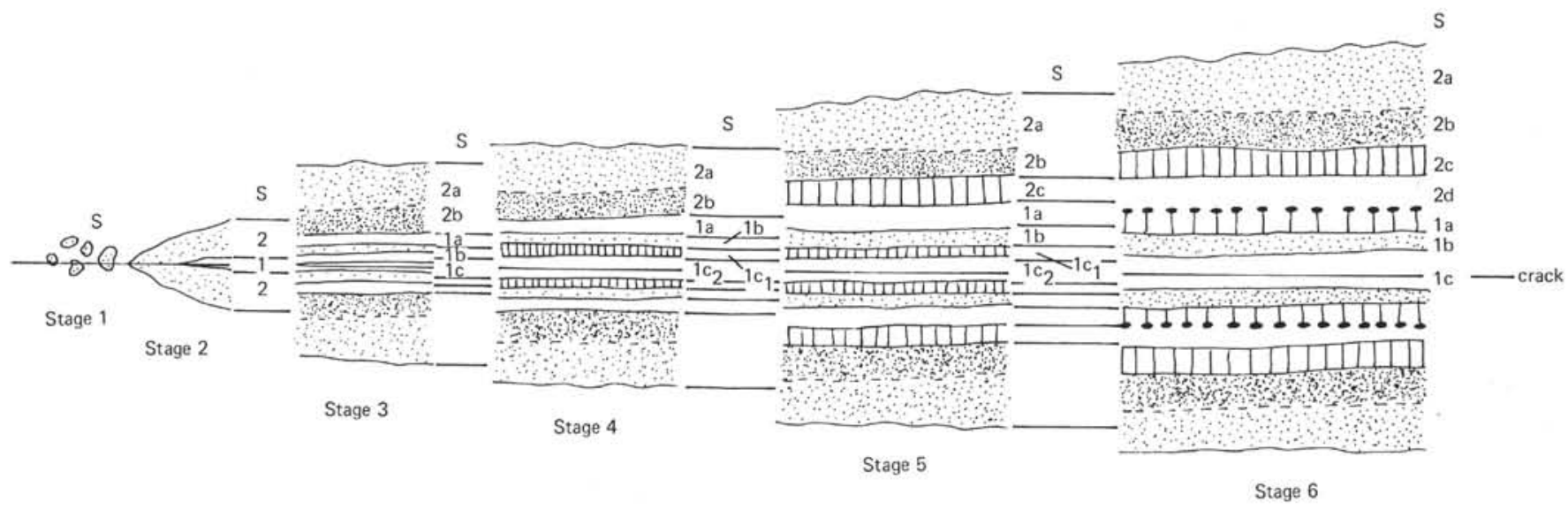

Figure 4. Development of alteration layers along a crack in fresh glass (glassy zone GZ), Sample 417D-27-1, 82-86 cm.
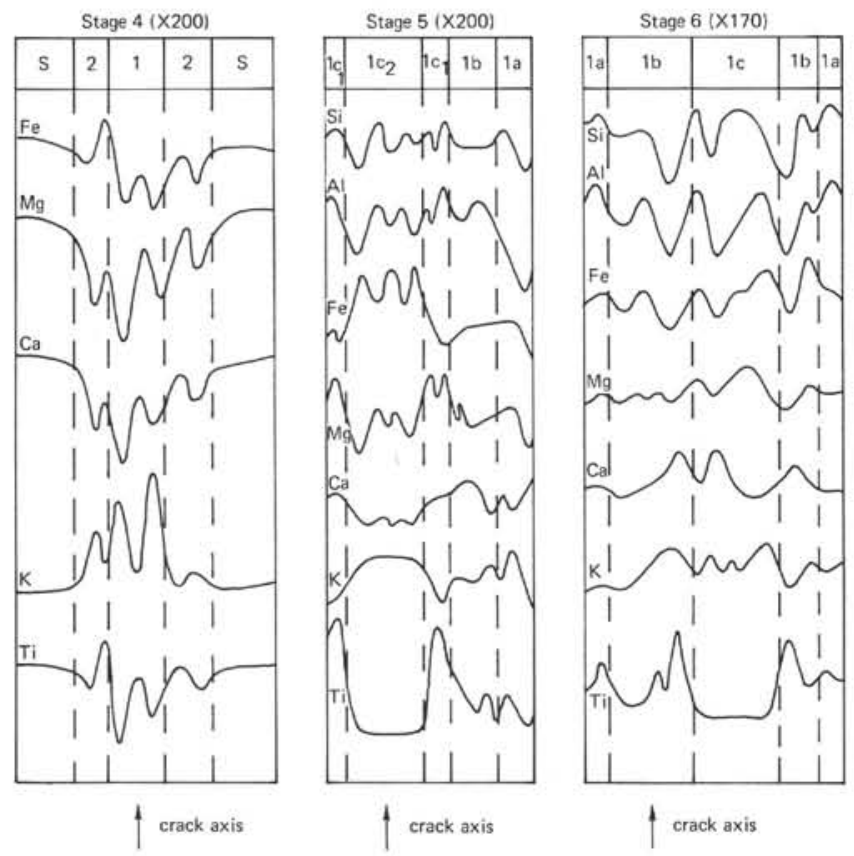

Figure 5. Electron scanning profiles across alteration layers in the same crack (see Figure 4).

crystallization is lacking. As usual, the alteration begins by the core of the phenocrysts, the margins remaining often untouched. Clinopyroxene phenocrysts are not altered.

\section{Alteration of the Mesostasis in the Pillow Cores}

The interstitial glass in the pillow cores is transformed to a microcrystalline mixture of iron oxides, hydroxides, and smectites.

\section{Vesicles and Veinlets}

The vesicles and veinlets are filled with the same minerals already described in Hole 417D, with the same order of succession (Figure 7C, 7D, 7E, 7G). These minerals are lamellae of green smectite ("protoceladonite?'), normal to the wall of the vesicle or veinlet; microcrystalline green smectite; trioctahedral brownish smectite; and calcite.

\section{Evolution of Alteration With Depth}

Table 3 gives the list of samples analyzed in this study, their depth, nature, and secondary mineralogy (phenocrysts, vesicles, veinlets, matrix of hyaloclastic breccias). No notable variations with depth were observed,

\section{CHEMISTRY OF ALTERATION}

\section{Major Elements}

\section{Chemical Balance of the Palagonitization}

Table 4 shows microprobe analysis of fresh glasses from Leg 51. $F_{1}$ is the average of 98 analyses of fresh glass made by Sinton and Byerly (Smithsonian Institution) in samples distributed in the whole basaltic section of Hole 417D. $\mathrm{F}_{2}$ and $F_{3}$ are two microprobe analyses of fresh glass made by Mevel (this volume) in the same hole, one at the top and the other at the bottom of the basaltic section. $F_{2}$ and $F_{3}$ show a remarkable invariability of the glass composition, and an excellent agreement with Sinton and Byerly's standard average. $F_{4}$ and $F_{5}$ show strong similarities to the compositions of younger fresh glasses from Sites 332 and 335 (after Scarfe and Smith, 1977).

Table 5 gives the complete compositions (with $\mathrm{Fe}_{2} \mathrm{O}_{3}$, $\mathrm{CO}_{2}, \mathrm{H}_{2} \mathrm{O}$ ) of six palagonites from Hole $417 \mathrm{~A}$ (Columns 3 to 8 ), compared to two analyses of palagonites from the 

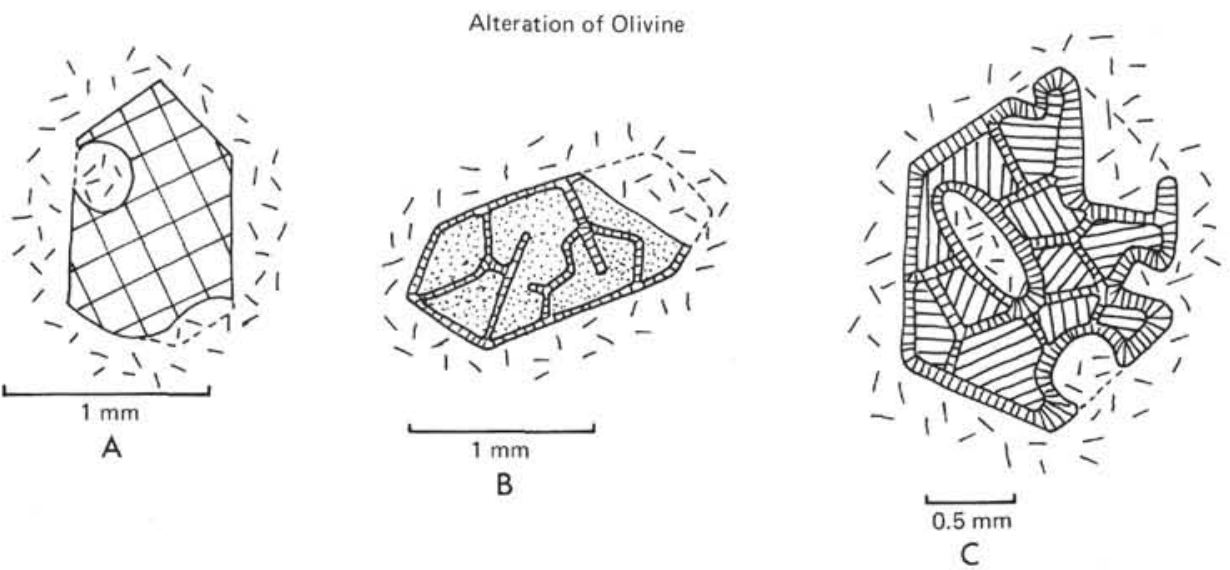

Alteration of Plagioclase
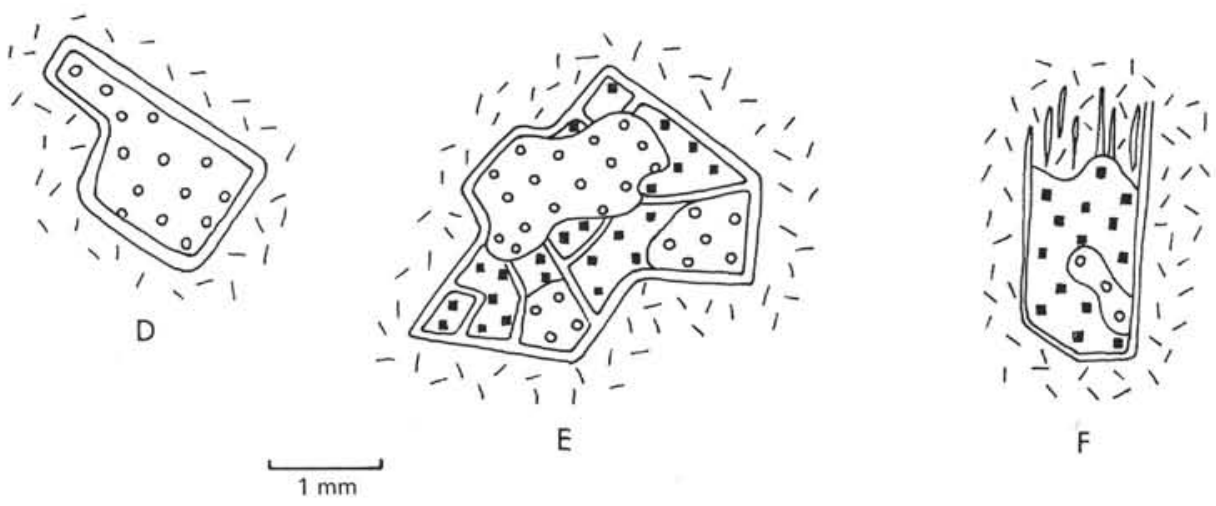

$\mathrm{F}$

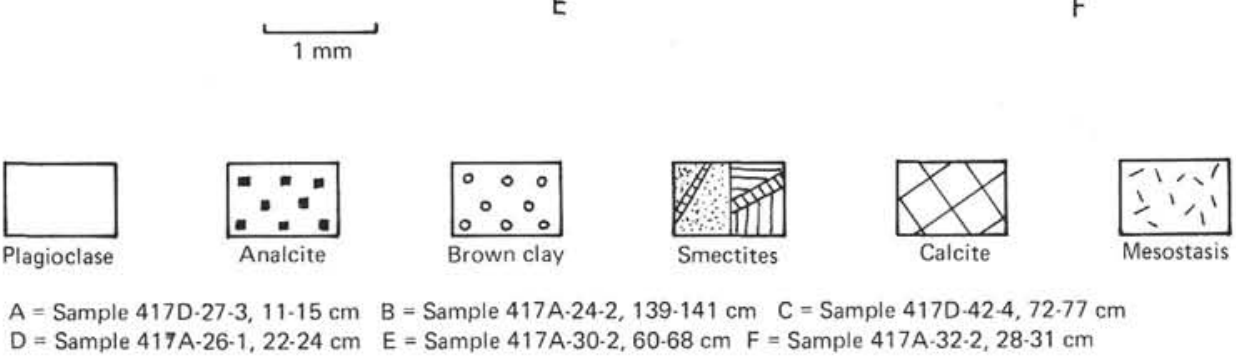

Figure 6. Alteration of phenocrysts in the basalts of the two holes: some examples.

same younger sites (Scarfe and Smith, 1977; Columns 1 and 2). After correction for the amount of calcite, the six analyses of Hole 417A are quite homogeneous: Table 6 gives the corresponding cationic and structural formulas. These are global formulas that do not take into account the morphological and chemical heterogeneities previously described. The three formulas given in this table correspond to the samples devoid of phillipsite, where all $\mathrm{Na}$ cations occupy interlayer positions in the palagonite.

Direct comparison of Tables 4 and 5 gives a first idea of major oxides behavior during the palagonitization: there is a loss of $\mathrm{SiO}_{2}$, total $\mathrm{FeO}, \mathrm{MgO}, \mathrm{Na}_{2} \mathrm{O}$, and $\mathrm{TiO}_{2}$ and an enrichment in $\mathrm{K}_{2} \mathrm{O}$ and $\mathrm{H}_{2} \mathrm{O}$. Assuming that the $\mathrm{H}_{2} \mathrm{O}$ content in the fresh glass is $<1$ per cent, the strongest variations are for $\mathrm{CaO}(>11 \%$ to $<1 \%)$ and $\mathrm{H}_{2} \mathrm{O}(<1 \%$ to $>15 \%)$. $\mathrm{Al}_{2} \mathrm{O}_{3}$ is slightly enriched. The ratio of $\mathrm{Fe}_{2} \mathrm{O}_{3}$ over $\mathrm{FeO}$ is very high in the analyzed palagonites, but the enrichment in $\mathrm{Fe}_{2} \mathrm{O}_{3}$ cannot be estimated because of the microprobe analysis of the fresh glass, which give only the total $\mathrm{Fe}$. A rather good negative correlation exists between $\mathrm{SiO}_{2}$ and $\mathrm{K}_{2} \mathrm{O}$ (Figure 12).

\section{Evolution of Palagonitization With Time}

With the data already available about the compositions of fresh glasses and corresponding palagonites of Legs 37 and 51 , we tried to estimate the chemical variations during the palagonitization process as a function of time.

We assume the following: (a) that the fresh glasses from Sites 332, 335, and 417 are 3.5, 9, and 110 m.y.B.P., respectively; (b) that the composition of the "young" fresh glasses from Sites 332 and 335 are represented by Analyses $\mathrm{F}_{4}$ and $\mathrm{F}_{5}$, respectively (Table 4 ), and the corresponding palagonites by Analyses 1 and 2 (Table 5), respectively; (c) that the composition of the "old" fresh glasses from Hole 417A are represented by Analysis $F_{1}$ (Table 4), an average of 98 microprobe analyses of glasses from Hole 417D, and 


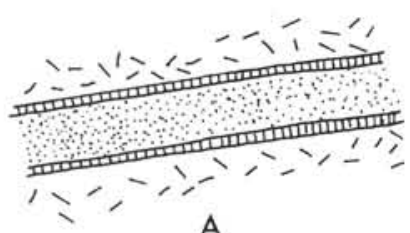

A

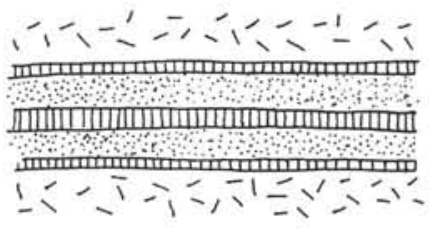

B

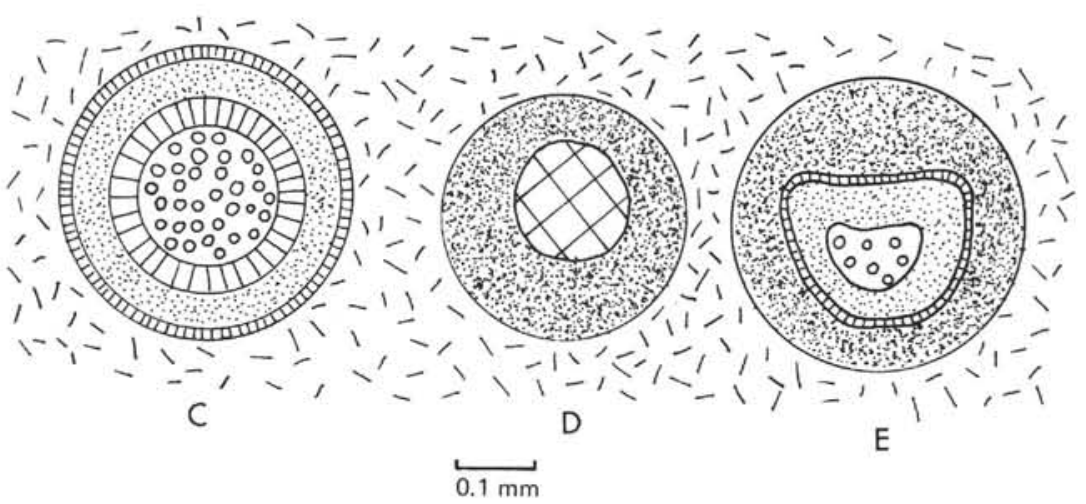

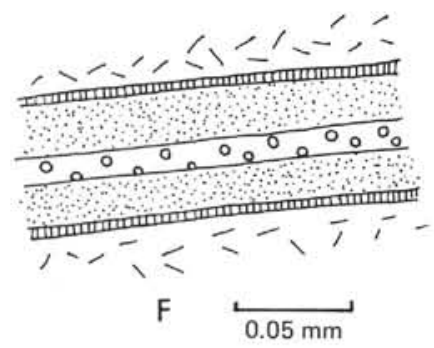

\begin{tabular}{r||} 
Green phyllites \\
\\
\end{tabular}

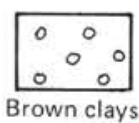

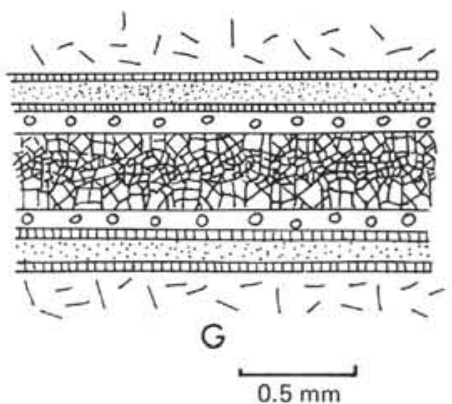

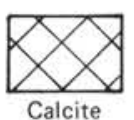

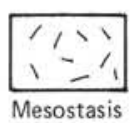

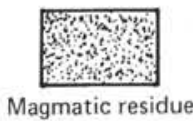

Figure 7. Veins and vesicles in Leg 51. (A) Sample 417D-28-5, 143-146 cm, vein with green phyllites; (B) Sample 41 7D-26-3, 74-78 cm, vein with green phyllites; (C) Sample 417A26-1, 22-24 cm, vesicle with green phyllites and brown clays; (D) Sample 417A-29-6, $42-48 \mathrm{~cm}$, segregation vesicle with calcite; (E) Sample 417A-26-1, 30-39 cm, segregation vesicle with green phyllites and brown clays; $(F)$ Sample 417D-28-5, 143-146 cm, vein with green phyllites and brown clays; $(G)$ Sample $417 A-25-2,19-22 \mathrm{~cm}$, vein with green phyllites, brown clays, and calcite.

the palagonites by Analyses A-11 and C-10. We have retained these two analyses among the six analyses of Table 5 because we could measure the density of the two samples in good conditions. As we have already noticed, the bulk compositions of all fresh glasses are very close (Table 4). The fresh glass of Site 335 is somewhat richer in $\mathrm{MgO}$ and $\mathrm{Al}_{2} \mathrm{O}_{3}$ and poorer in $\mathrm{FeO}$ and $\mathrm{TiO}_{2}$ than the other ones.

Table 7 gives the mass variations of major oxides (in $\mathrm{g} / 100 \mathrm{~cm}^{3}$ ) after alteration of the fresh glasses. The calculation is possible if the density of fresh glasses and palagonites are known. For samples from Leg 37, we measured a density of 2.75 for the fresh glass, 1.74 for the palagonite of Hole $332 \mathrm{~A}$, and 1.91 for the palagonite of Site 335 . For samples from Leg 51 , we measured a density of 2.78 for the fresh glass and 2.34 (Column 3) to 2.36
(Column 4) for the palagonite. Table 7 shows systematic losses of $\mathrm{SiO}_{2}, \mathrm{Al}_{2} \mathrm{O}_{3}, \mathrm{MgO}, \mathrm{CaO}$, and $\mathrm{Na}_{2} \mathrm{O}$ in the four cases; systematic enrichment in $\mathrm{K}_{2} \mathrm{O}$; and enrichment in total $\mathrm{FeO}$ and $\mathrm{TiO}_{2}$ only for the "young" glasses and losses of these elements in the "old"' glasses of Leg 51.

Taking into account the age of the glasses, an average rate of chemical variation per year can be calculated for each major oxide (Table 8), which confirms the general tendencies described above and shows a systematic decrease of the rates of exchanges towards zero with time.

This comparison between the glasses from Legs 37 and 51 is an attempt to characterize the behavior of the different major elements during the palagonitization process and the evolution of the rates of chemical exchanges with time. Nevertheless, it must be noted that more than the absolute 
A

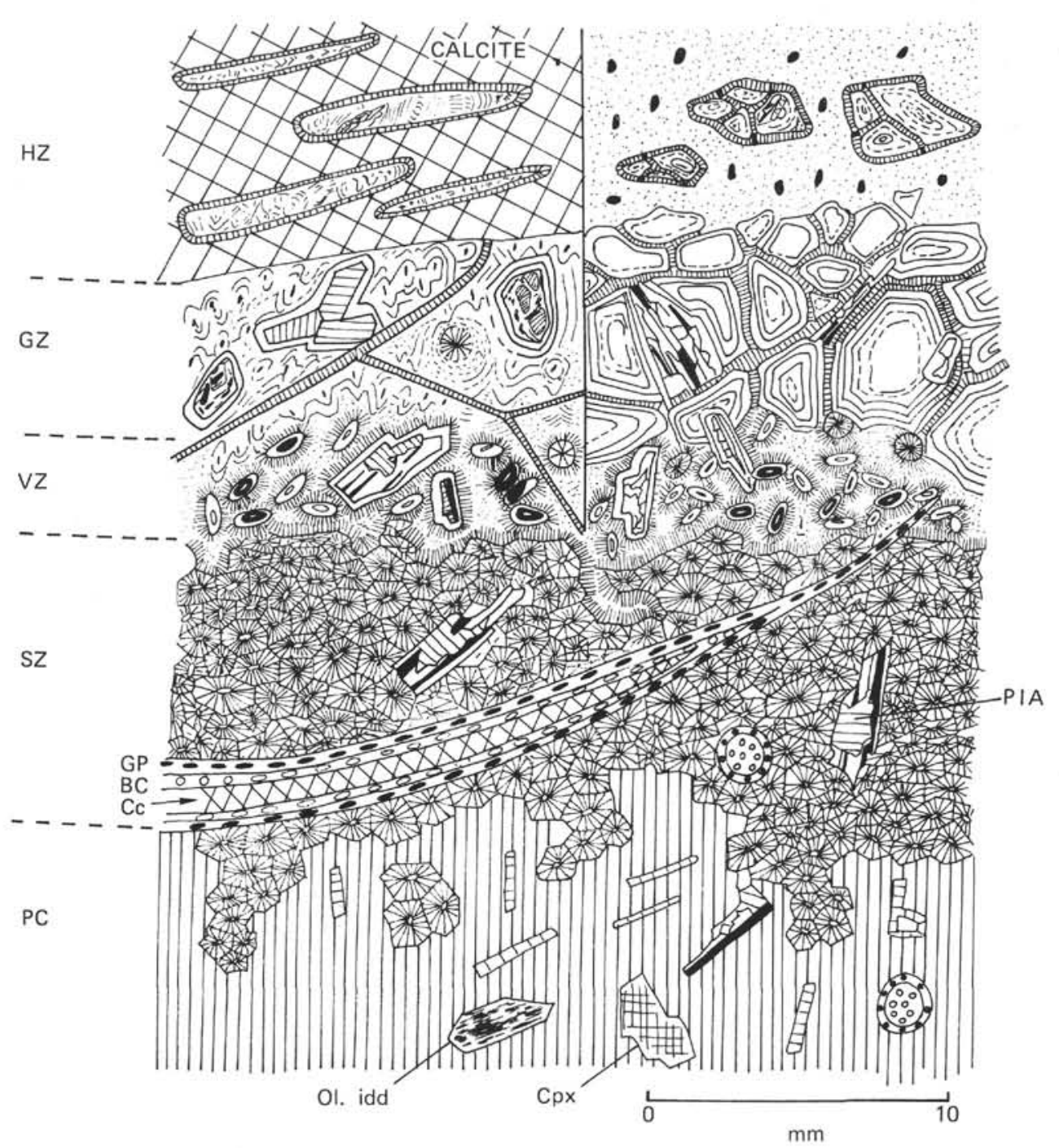

Figure 8. Synthetic section of a pillow margin, Hole $417 A$, with the same typical concentric structure already described in Figure 1. HZ = hyaloclastic zone; $A=$ elongated palagonitic green fragments, coming from a poorly fractured glassy zone, in a calcitic matrix; $B=$ angular green and brown palagonitic fragments, coming from a highly fractured margin, in a complex fine-grained matrix (clays, iron oxides, zeolites, calcite). $G Z=$ glassy zone; $A=$ poorly fractured, with palagonitic rims developing around the phenocrysts; $B=$ highly fractured, with palagonitic concentric layers developing parallel to the fractures. $V Z=$ variolitic zone. $S Z=$ spherulitic zone. $P C=$ pillow core. Phenocrysts: PlA $=$ analcitized plagioclase $;$ Ol. idd. $=$ iddingsitized olivine $;$ Cpx $=$ fresh clinopyroxene. Veinlets, fractures, and segregation vesicles (SV) are filled with green $(G P)$ and brown smectites $(B C)$, and calcite $(C c)$.

age of the glass, the actual time of contact of this glass with sea water is the most important parameter, as demonstrated by the strong differences between Holes 417A and 417D.

We do not know exactly when the alteration begins to be effective in a fresh glass in contact with sea water. We can only observe that the palagonite of Hole 332A, developed in a glass $3.5 \mathrm{~m}$.y. old, has $\sim 15$ per cent $\mathrm{H}_{2} \mathrm{O}$ and a density of 1.74 (against 2.75 in the fresh glass). This strong hydration of the glass is accompanied by chemical exchanges, either by diffusion or by mechanical tearing out (Trichet, 1970), or by both processes. At the beginning, the elements $\mathrm{Si}, \mathrm{Al}$,
$\mathrm{Mg}, \mathrm{Ca}$, and $\mathrm{Na}$ are leached from the glass, and the elements $\mathrm{K}, \mathrm{Fe}$, and $\mathrm{Ti}$ are concentrated in the residual glass. $\mathrm{Si}, \mathrm{Al}, \mathrm{Ca}$, and $\mathrm{Na}$ are immediately used to form zeolites and calcite in the matrix of the hyaloclastites. As for the potassium, it passes from sea water into the glass, as demonstrated by several authors (Bonatti, 1970; Hay and Iijima, 1968; Moore, 1966). These tendencies in the chemical behavior of major elements are maintained with time, except for $\mathrm{Fe}$ and $\mathrm{Ti}$, which are finally leached also from the residual glass. All these exchanges tend to reach an equilibrium, with the rates of exchanges tending to zero. 


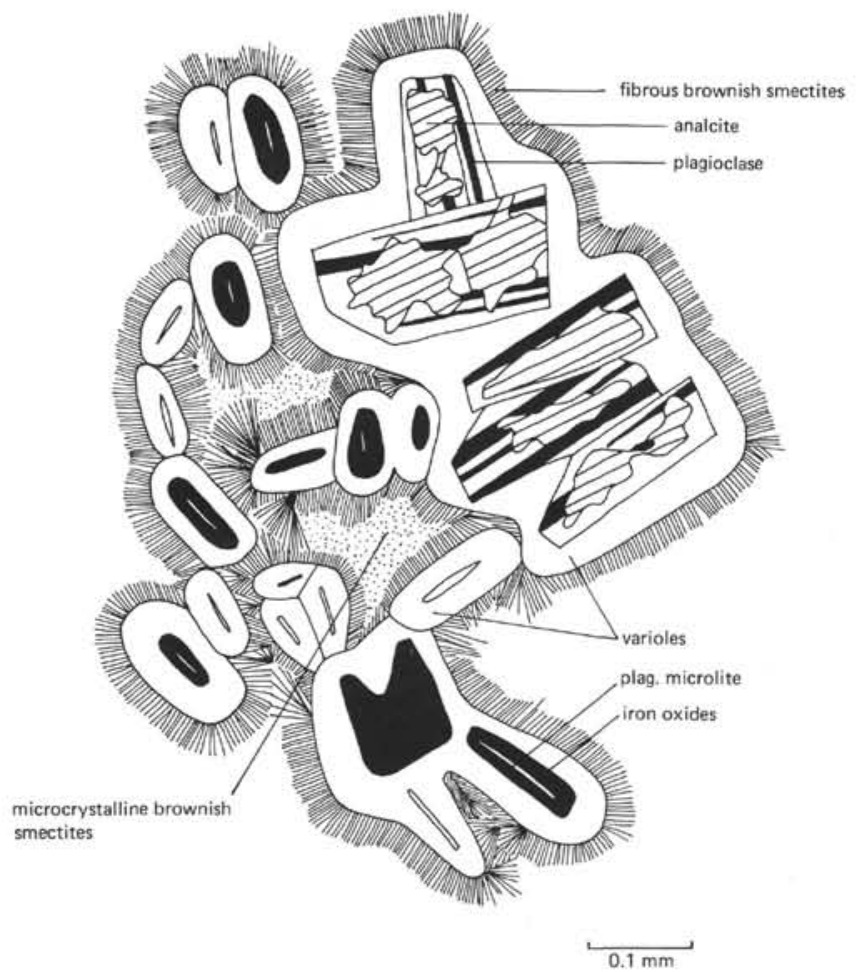

Figure 9. Alteration of the variolitic zone (VZ), Hole $417 \mathrm{~A}$ (detail).

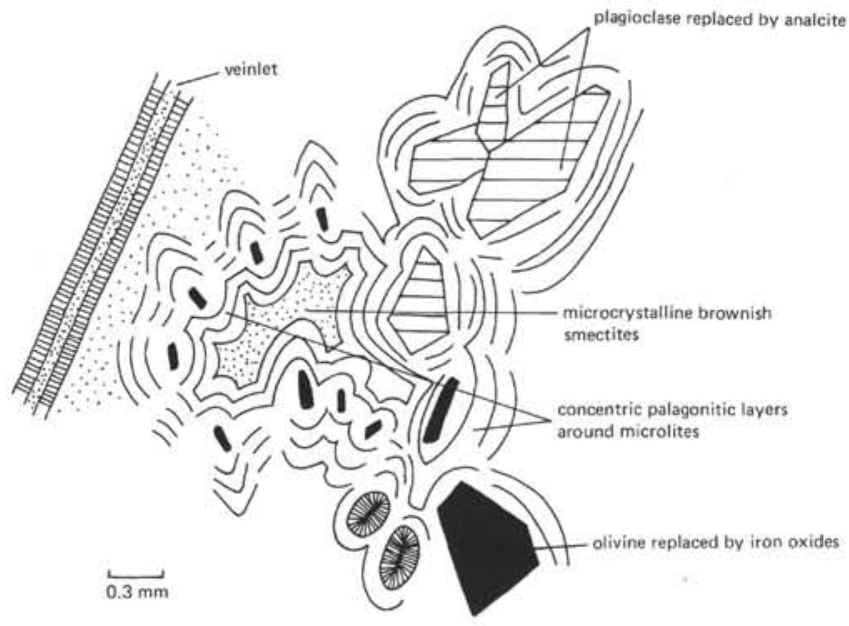

Figure 10. Alteration of the poorly fractured glassy zone (GZ), Hole 417A (detail).

The altered glass converts to a mineral association stable in the PT conditions of the sea floor; this state of equilibrium is almost attained in Hole 417A.

\section{Chemical Balance of the Alteration of Basalts}

\section{Alteration of the Basalts of Leg 51}

Table 9 gives complete analysis of three pillow cores from Hole 417D. Their low content in $\mathrm{K}_{2} \mathrm{O}(<0.25 \%)$ is a good criterion of freshness (Hart, 1976; Thompson, 1973, Dymond, 1973; Andrews, 1977), as also their low ratio of $\mathrm{Fe}_{2} \mathrm{O}_{3} / \mathrm{FeO}$, close to 0.5 . These compositions are those of typical oceanic tholeiites. Table 10 gives complete analysis of six altered pillow cores from Hole 417A, Column 2 (shallowest sample) to 7 (deepest sample), and for comparison an altered pillow core from Site 10 (Leg 2) estimated to be $16 \mathrm{~m} . \mathrm{y}$. old (Thompson, 1973). The more striking differences between fresh and altered pillow cores are the strong enrichment of the latter in $\mathrm{K}_{2} \mathrm{O}(1.1$ to $4.6 \%)$ and $\mathrm{H}_{2} \mathrm{O}$ (4.7 to $10.1 \%$ ), and higher values for the $\mathrm{Fe}_{2} \mathrm{O}_{3} / \mathrm{FeO}$ ratio ( 1.5 to 6$)$. Table 10 shows also that these values have a general tendency to diminish with depth, confirming that the alteration diminishes with depth in this hole, as already noted during the shipboard studies.

These relationships can be visualized in Figures 13, 14, and 15, where three analyses of fresh basalts from Hole 417D, the analysis of one altered basalt from Site 10, and the six analyses of altered pillow cores from Hole 417A have been plotted. Figure 13 shows a good correlation between $\mathrm{H}_{2} \mathrm{O}$ and $\left(\mathrm{Na}_{2} \mathrm{O}+\mathrm{K}_{2} \mathrm{O}\right)$, and Figure 14 shows a good correlation between $\mathrm{H}_{2} \mathrm{O}$ and $\mathrm{Fe}_{2} \mathrm{O}_{3} / \mathrm{FeO}$. In the two cases, the representative points plot along the correlation straight line in the order of intensity of alteration: fresh basalts at the left (low contents in $\mathrm{H}_{2} \mathrm{O}, \mathrm{Na}_{2} \mathrm{O}+\mathrm{K}_{2} \mathrm{O}$, low $\mathrm{Fe}_{2} \mathrm{O}_{3} / \mathrm{FeO}$ ratio), then the sample from Site 10 ("young", altered basalt), then the six "old"' altered basalts from Hole $417 \mathrm{~A}$, in the inverse order of depth. Figure 15 shows the same evolution, with progressive enrichment of the samples (in the same order) in alkalines and $\mathrm{H}_{2} \mathrm{O}$, and concomitant relative loss of $\mathrm{SiO}_{2}$.

\section{Evolution With Time}

Table 11 gives the balance of mass variations of the major oxides (in $\mathrm{g} / 100 \mathrm{~cm}^{3}$ ) for basalts at 16,80 , and 110 m.y.B.P. In all three cases, the balance is negative for $\mathrm{SiO}_{2}$, total $\mathrm{FeO}, \mathrm{MgO}, \mathrm{CaO}$, and $\mathrm{Na}_{2} \mathrm{O}$, and positive for $\mathrm{K}_{2} \mathrm{O}$ and $\mathrm{H}_{2} \mathrm{O}$. For $\mathrm{Al}_{2} \mathrm{O}_{3}$ and $\mathrm{MnO}$, the balance is negative for the two first basalts, and positive for the third (oldest) one. The quantities of oxides leached from the basalts are lesser than from the glasses, especially for $\mathrm{CaO}$. The rates of chemical exchanges per year (Table 12) are also lesser than in the glasses, but show the same tendency to diminish and trend towards zero with time.

\section{Rare-Earth Elements}

Two types of samples have been selected for this study: fresh pillow lavas from Hole 417D, and altered pillow lavas from Hole 417A (where alteration is one of the deepest ever seen until now in the DSDP drillings). All of the samples have been taken in the glassy margins.

The analysis of REE has been made by neutron activation (Treuil et al., 1973; Courtois and Jaffrezic-Renault, 1977); the results are reported in Table 13. Normalizations have been made either with respect to chondrites for fresh basalts from Hole 417D (Figure 16), or with respect to one of the fresh samples (Sample 417D-66-5, 32-36 cm, \#12) for the altered samples from Hole 417A (Figure 17).

REE contents of fresh basalts range from 10 to $20 \mathrm{ppm}$ for the sum of analyzed elements and are then of the same order of magnitude than usual in oceanic basalts (Frey and Haskin, 1946; Frey et al., 1968). The distribution curves are characterized by impoverishment in light REE, especially $\mathrm{La}$ and $\mathrm{Ce}$, with respect to chondrites. This classical distribution is typical of oceanic tholeiites. 


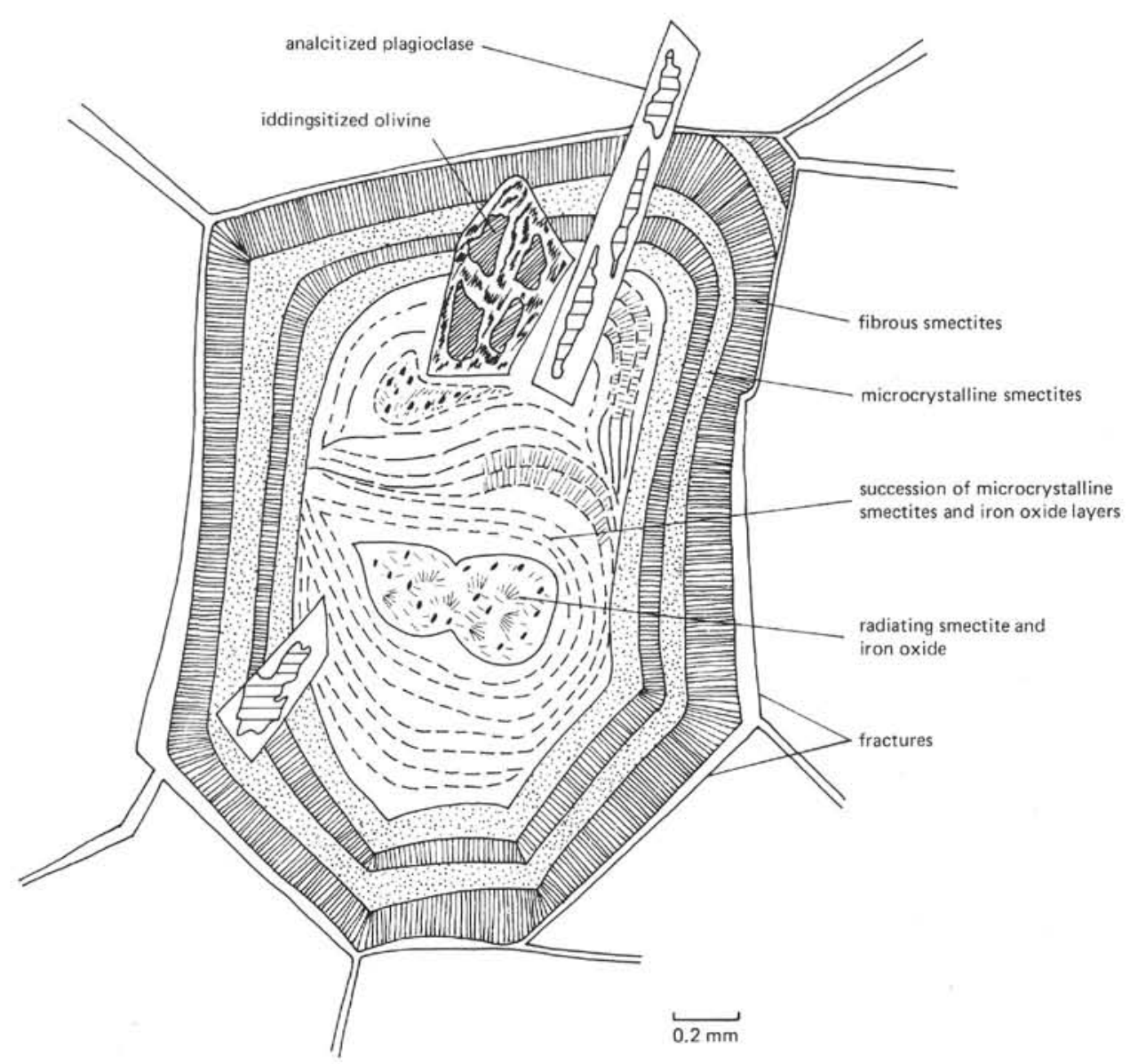

Figure 11. Alteration of the highly fractured glassy zone (GZ), Hole 417A (detail).

The distribution curves of altered samples from Hole 417A (Figure 17) are characterized by a fractionation with respect to the fresh basalt chosen as reference. This fractionation consists in an enrichment in the lightest REE ( $\mathrm{La}, \mathrm{Ce}$, and $\mathrm{Nd}$ ), while heavy REE remain quite unchanged.

This selective immobilization of the lightest REE has already been observed by Frey et al. (1974) in altered glasses from Legs 2 and 3, and by Juteau et al. (1979) in Leg 45 samples.

Moreover, cerium is relatively more enriched than its two neighbors ( $\mathrm{La}$ and $\mathrm{Nd}$ ), and presents positive anomalies. These anomalies do not have all the same intensity; they are less important for the two deepest samples.

Thus it seems that alteration is here advanced enough to induce a fractionation in the REE family. The consequences of a selective immobilization of light REE in alteration products of pillow lavas are important to explain the distribution of REE in sea water. Effectively, the distribution curve of REE in sea water is characterized by an important negative anomaly of cerium and by a relative enrichment in heavy REE (Hogdahl et al., 1968).

The cortex of manganese nodules is frequently strongly enriched in Ce (Ehrlich, 1968) and has been claimed to be responsible for the deficit of sea water in cerium. Now here the alteration products of basalts are also enriched in light REE and especially in $\mathrm{Ce}$. The pattern of the distribution curves of REE in solution thus will be modified when compared to that of fresh basalts. In spite of a very low mobility of these elements, it can be thought that the REE distribution of the solution will be the reverse of that of the residual products, with a deficit in cerium and a relative enrichment in heavy REE, a distribution which is actually observed in sea water.

In such oceanic areas, far from the continental clastic sedimentation which can re-equilibrate and homogenize the distribution spectrum of the REE in sea water, the submarine alteration of basalts can, at least in the case studied here, constitute a supplementary factor to explain the fractionation and cerium anomaly in the solution.

\section{ACKNOWLEDGMENTS}

This study was conducted in tight collaboration with Catherine Mevel (Laboratoire de Pétrographie, Université Pierre et Marie Curie, Paris, France), who made the microprobe analysis on the same samples. Her paper is in many aspects complementary to ours. We want to thank her for helpful discussions and meetings we had together during the past year. We want also to thank the Centre National de la Recherche Scientifique for financial support (Action Tehématique Programmée "soutien à IPOD”).

\section{REFERENCES}

Andrews, A.J., 1977. Low temperature fluid alteration of oceanic layer 2 basalts, DSDP Leg 37, Canadian J. Earth Sci., v. 14, p. 911-926.

Baragar, W.R.A., Plant, A.G., Pringle, G.T., and Schau, M., 1977. Petrology and alteration of selected units of Mid-Atlantic Ridge basalts samples from Sites 332 and 335, DSDP, Canadian J. Earth Sci., v. 14, p. 837-874. 
TABLE 3

Secondary Mineralogy in Hole 417A

\begin{tabular}{|c|c|c|c|c|c|c|c|c|c|c|c|c|c|c|}
\hline \multirow{2}{*}{$\begin{array}{l}\text { Lithologic } \\
\text { Units }\end{array}$} & \multirow{2}{*}{$\begin{array}{c}\text { Sample } \\
\text { (Interval in } \mathrm{cm} \text { ) }\end{array}$} & \multirow{2}{*}{$\begin{array}{l}\text { Sub-Bottom } \\
\text { Depth } \\
\text { (m) }\end{array}$} & \multirow[b]{2}{*}{ (1) } & \multirow[b]{2}{*}{$\mathrm{Cc}$} & \multicolumn{3}{|c|}{ PL Phenocrysts } & \multirow[b]{2}{*}{ Cha } & \multicolumn{4}{|c|}{ Veins, Vesicles } & \multirow[b]{2}{*}{ (2) } & \multirow[b]{2}{*}{ (3) } \\
\hline & & & & & $\mathrm{BC}$ & $\mathrm{Fk}$ & An & & $\mathrm{Cc}$ & $\mathrm{BC}$ & GP & An & & \\
\hline $2 a$ & $24-2,65-67$ & 219.6 & GM & + & + & & & & + & & + & & + & \\
\hline $2 \mathrm{~b}$ & $\begin{array}{l}24-2,139-141 \\
24-3,21-23 \\
24-3,27-29 \\
24-3,40-44 \\
24-3,103-107 \\
25-1,28-34 \\
25-2,11-15 \\
25-2,19-22 \\
26-1,22-24 \\
26-1,30-39 \\
26-1,64-66 \\
26-1,96-101\end{array}$ & $\begin{array}{l}220.4 \\
220.7 \\
220.8 \\
220.9 \\
221.5 \\
227.3 \\
228.6 \\
228.7 \\
236.7 \\
236.8 \\
237.1 \\
237.5\end{array}$ & $\begin{array}{l}\text { GM } \\
\text { GM } \\
\text { GM } \\
\text { GM } \\
\text { PC } \\
\text { PC } \\
\text { PC } \\
\text { PC } \\
\text { PC } \\
\text { PC } \\
\text { PC } \\
\text { GM }\end{array}$ & $\begin{array}{l}+ \\
+ \\
+ \\
+ \\
+ \\
+\end{array}$ & $\begin{array}{l}+ \\
+ \\
+ \\
+ \\
+ \\
+ \\
+ \\
+ \\
+ \\
+ \\
+ \\
+\end{array}$ & $\begin{array}{r}+ \\
+\end{array}$ & + & & $\begin{array}{l}+ \\
+ \\
+ \\
+ \\
+ \\
+ \\
+ \\
+ \\
+ \\
+ \\
+\end{array}$ & $\begin{array}{l}+ \\
+ \\
+ \\
+\end{array}$ & $\begin{array}{l}+ \\
+ \\
+ \\
+ \\
+\end{array}$ & & + & \\
\hline 3 & $\begin{array}{l}26-2,25-27 \\
26-2,117-123 \\
26-2,140-146\end{array}$ & $\begin{array}{l}238.2 \\
239.2 \\
239.4\end{array}$ & $\begin{array}{l}\text { MB } \\
\text { GM } \\
\text { GM }\end{array}$ & + & $\begin{array}{l}+ \\
+\end{array}$ & & & & $\begin{array}{l}+ \\
+ \\
+\end{array}$ & $\begin{array}{l}+ \\
+\end{array}$ & $\begin{array}{l}+ \\
+\end{array}$ & & + & \\
\hline 4 & $\begin{array}{l}26-5,67-69 \\
26-5,87-89 \\
26-5,99-101\end{array}$ & $\begin{array}{l}243.2 \\
243.4 \\
243.5\end{array}$ & $\begin{array}{l}\text { GM } \\
\text { GM } \\
\text { PC }\end{array}$ & + & $\begin{array}{l}+ \\
+\end{array}$ & $\begin{array}{l}+ \\
+\end{array}$ & + & + & + & $\begin{array}{l}+ \\
+ \\
+\end{array}$ & $\begin{array}{l}+ \\
+\end{array}$ & & & \\
\hline 5 & $28-1,50-52$ & 256.0 & $\mathrm{PC}$ & + & + & & & & + & & + & & & \\
\hline $\begin{array}{l}6 \\
7\end{array}$ & $\begin{array}{l}28-2,63-67 \\
28-2,89-95\end{array}$ & $\begin{array}{l}257.6 \\
257.9\end{array}$ & $\begin{array}{l}\text { GM } \\
\text { PC }\end{array}$ & + & + & + & & + & $\begin{array}{l}+ \\
+\end{array}$ & + & + & & & \\
\hline 8 & $\begin{array}{l}28-5,105-111 \\
29-1,98-100 \\
29-4,24-27 \\
29-6,42-48 \\
30-1,32-37 \\
30-1,45-47\end{array}$ & $\begin{array}{l}262.5 \\
266.0 \\
269.7 \\
272.9 \\
274.8 \\
274.9\end{array}$ & $\begin{array}{l}\text { GM } \\
\text { MB } \\
\text { GM } \\
\text { PC } \\
\text { GM } \\
\text { GM }\end{array}$ & $\begin{array}{l}+ \\
+ \\
+ \\
+\end{array}$ & $\begin{array}{l}+ \\
+ \\
+ \\
+ \\
+ \\
+\end{array}$ & $\begin{array}{l}+ \\
+\end{array}$ & + & + & $\begin{array}{l}+ \\
+ \\
+ \\
+ \\
+ \\
+\end{array}$ & $\begin{array}{l}+ \\
+ \\
+\end{array}$ & $\begin{array}{l}+ \\
+ \\
+\end{array}$ & & + & + \\
\hline 9 & $30-2,60-68$ & 276.6 & GM & & + & + & + & & + & + & + & & & \\
\hline 10 & & & & & & & & & & & & & & \\
\hline 11 & $\begin{array}{l}30-5,64-57 \\
31-2,39-42\end{array}$ & $\begin{array}{l}281.1 \\
285.9\end{array}$ & $\begin{array}{l}\mathrm{PC} \\
\mathrm{H}\end{array}$ & + & + & & & & + & + & + & & & \\
\hline 12 & $\begin{array}{l}31-3,117-120 \\
32-1,118-121 \\
32-2,28-31 \\
32-4,66-69\end{array}$ & $\begin{array}{l}288.2 \\
294.7 \\
295.3 \\
298.9\end{array}$ & $\begin{array}{l}\mathrm{PC} \\
\mathrm{H} \\
\mathrm{GM} \\
\mathrm{GM}\end{array}$ & + & + & + & $\begin{array}{l}+ \\
+\end{array}$ & & + & $\begin{array}{l}+ \\
+ \\
+\end{array}$ & & + & + & $\begin{array}{l}+ \\
+\end{array}$ \\
\hline 13 & $32-5,77-82$ & 300.3 & GM & + & + & & + & & + & + & + & + & & \\
\hline 14 & $\begin{array}{l}33-5,51-54 \\
34-1,127-129\end{array}$ & $\begin{array}{l}309.5 \\
313.8\end{array}$ & $\begin{array}{l}\text { PC } \\
\text { GM }\end{array}$ & & + & & $\begin{array}{l}+ \\
+\end{array}$ & & + & & & & & \\
\hline 15 & & & & & & & & & & & & & & \\
\hline 16 & $\begin{array}{l}35-3,71-74 \\
35-5,2-6 \\
38-3,122-125 \\
40-3,111-116 \\
41-1,141-146 \\
42-3,123-128\end{array}$ & $\begin{array}{l}325.7 \\
328.0 \\
351.7 \\
367.2 \\
371.0 \\
382.8\end{array}$ & $\begin{array}{l}\text { PC } \\
\text { GM } \\
\text { PC } \\
\text { PC } \\
\text { PC } \\
\text { GM }\end{array}$ & $\begin{array}{l}+ \\
+\end{array}$ & $\begin{array}{l}+ \\
+ \\
+ \\
+ \\
+ \\
+\end{array}$ & $\begin{array}{l}+ \\
+\end{array}$ & $\begin{array}{l}+ \\
+\end{array}$ & + & $\begin{array}{l}+ \\
+ \\
+\end{array}$ & $\begin{array}{l}\text { Goe } \\
+ \\
+\end{array}$ & $\begin{array}{c}+ \\
\text { thite } \\
+\end{array}$ & + & + & + \\
\hline
\end{tabular}

Note: Recomputed depth value. Column $1=$ nature of the samples, $\mathrm{H}=$ hyaloclastic breccias, $\mathrm{GM}=$ glassy margins, $\mathrm{PC}=$ pillow cores, $\mathrm{MB}=$ massive basalts; Plagioclase phenocrysts: $\mathrm{Cc}=$ calcite, $\mathrm{Bc}=$ brown smectites, $\mathrm{Fk}=$ potassic feldspar, $\mathrm{An}=$ analcite, $\mathrm{Cha}=$ chabazite; Veins and vesicles: same symbols, $\mathrm{GP}=$ green smectites; Column $2=$ calcitic matrix with phillipsite; Column 3 = matrix of phillipsite.

Bass, M.N., 1976. Secondary minerals in oceanic basalt, with special reference to Leg 34, DSDP. In Yeats, R.S., Hart, S.R., et al., Initial Reports of the Deep Sea Drilling Project, v. 34: Washington (U.S. Government Printing Office), p. 392-432.

Bonatti, E., 1970. Deep-sea volcanism, Naturwissenchaften, v. 57 , p. $379-384$
Bryan, W.B., 1972. Morphology of quench crystals in submarine basalts, J. Geophys. Res., v. 77, p. 5812-5819.

Courtois, C. and Jaffrezic-Renault, N., 1977. Utilisation des propriétés échangeuses d'ions du dioxyde d'étain pour l'analyse des

Frey, F.A. and Haskin, L.A., 1964. Rare earths in oceanic basalts, J. Geophys. Res., v. 69, p. 775-780. 
TABLE 4

Microprobe Analysis of Fresh Glass

\begin{tabular}{lcrrrr}
\hline & $\mathrm{F}_{1}$ & $\mathrm{~F}_{2}$ & $\mathrm{~F}_{3}$ & $\mathrm{~F}_{4}$ & \multicolumn{1}{c}{$\mathrm{F}_{5}$} \\
\hline $\mathrm{SiO}_{2}$ & 50.7 & 50.14 & 50.31 & 49.0 & 49.30 \\
$\mathrm{Al}_{2} \mathrm{O}_{3}$ & 14.3 & 14.86 & 14.80 & 13.8 & 15.50 \\
$\mathrm{FeO}$ & 11.5 & 11.52 & 12.30 & 10.1 & 9.40 \\
$\mathrm{MnO}$ & & 0.26 & 0.23 & 0.2 & 0.10 \\
$\mathrm{MgO}$ & 7.2 & 7.90 & 7.70 & 7.3 & 10.10 \\
$\mathrm{CaO}$ & 11.80 & 11.83 & 10.85 & 11.6 & 11.70 \\
$\mathrm{Na}_{2} \mathrm{O}$ & 2.30 & 2.18 & 2.42 & 1.9 & 2.50 \\
$\mathrm{~K}_{2} \mathrm{O}$ & 0.10 & 0.09 & 0.11 & 0.2 & 0.20 \\
$\mathrm{TiO}_{2}$ & 1.60 & 1.48 & 1.83 & 1.4 & 1.20 \\
\hline
\end{tabular}

Note: $\mathrm{FeO}$ as total iron. $\mathrm{F}_{1}=$ average of 98 analyses in Hole 417D, from Sinton and Byerly (Smithsonian Institution). $\mathrm{F}_{2}=$ Sample $417 \mathrm{D}$ 22-3, 99-101 cm, analyzed by C. Mevel. $\mathrm{F}_{3}=$ Sample 417D-62-3, 14-17 cm, analyzed by C. Mevel. $\mathrm{F}_{4}=$ analyzed from Hole $332 \mathrm{~A}$ (Scarfe and Smith, 1977). $F_{5}=$ analyzed from Site 335 (Scarfe and Smith, 1977).

TABLE 5

Chemical Analysis of Palagonites

\begin{tabular}{|c|c|c|c|c|c|c|c|c|c|}
\hline & & (1) & (2) & (3) & (4) & (5) & (6) & (7) & (8) \\
\hline & & $332 \mathrm{~A}$ & 335 & A 11 & C 6 & C 7 & C 8 & A 12 & C 10 \\
\hline \multirow{13}{*}{ 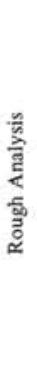 } & $\mathrm{SiO}_{2}$ & 44.40 & 42.60 & 38.20 & 46.39 & 44.26 & 38.67 & 47.10 & 43.95 \\
\hline & $\mathrm{Al}_{2} \mathrm{O}_{3}$ & 9.4 & 12.1 & 12.23 & 14.84 & 17.25 & 13.70 & 15.42 & 15.54 \\
\hline & $+\mathrm{Fe}_{2} \mathrm{O}_{3}$ & 19.0 & 17.0 & 8.59 & 9.95 & 9.88 & 8.16 & 8.37 & 10.75 \\
\hline & $(\mathrm{FeO})$ & & & $(0.23)$ & $(0.65)$ & & $(0.35)$ & $(0.37)$ & $(0.36)$ \\
\hline & $\mathrm{MnO}$ & & & 0.26 & 0.15 & 0.08 & 0.08 & 0.14 & 0.13 \\
\hline & $\mathrm{MgO}$ & 4.1 & 4.9 & 4.10 & 5.34 & 3.65 & 3.68 & 5.89 & 4.24 \\
\hline & $\mathrm{CaO}$ & 1.1 & 1.1 & 11.51 & 0.90 & 1.44 & 10.05 & 1.80 & 1.57 \\
\hline & $\mathrm{Na}_{2} \mathrm{O}$ & 0.2 & 1.9 & 0.81 & 1.52 & 1.17 & 1.26 & 2.77 & 1.18 \\
\hline & $\mathrm{K}_{2} \mathrm{O}$ & 3.3 & 3.0 & 2.06 & 3.44 & 4.08 & 2.92 & 1.74 & 3.87 \\
\hline & $\mathrm{TiO}_{2}$ & 2.9 & 2.2 & 0.82 & 0.72 & 1.43 & 0.93 & 0.65 & 1.29 \\
\hline & $\mathrm{H}_{2} \mathrm{O}^{2}$ & & & 12.52 & 16.29 & 15.30 & 12.64 & 15.23 & 16.81 \\
\hline & $\mathrm{CO}_{2}$ & & & 8.98 & 0.18 & 0.58 & 7.72 & 0.66 & 0.17 \\
\hline & Total & & & 100.08 & 99.72 & 99.12 & 99.81 & 99.77 & 99.50 \\
\hline \multirow{10}{*}{ 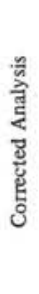 } & $\mathrm{SiO}_{2}$ & & & 47.95 & 46.71 & 45.25 & 47.10 & 47.93 & 44.34 \\
\hline & $\mathrm{Al}_{2} \mathrm{O}_{3}$ & & & 15.35 & 14.94 & 17.64 & 16.65 & 15.69 & 15.68 \\
\hline & $+\mathrm{FeO}$ & & & 9.99 & 9.67 & 9.09 & 9.26 & 8.05 & 10.13 \\
\hline & $\mathrm{MnO}$ & & & 0.33 & 0.15 & 0.08 & 0.10 & 0.14 & 0.13 \\
\hline & $\mathrm{MgO}$ & & & 5.15 & 5.37 & 3.73 & 4.47 & 5.99 & 4.28 \\
\hline & $\mathrm{CaO}$ & & & 0.10 & 0.67 & 0.71 & 0.27 & 0.98 & 1.36 \\
\hline & $\mathrm{Na}_{2} \mathrm{O}$ & & & 1.02 & 1.53 & 1.20 & 1.53 & 2.82 & 1.19 \\
\hline & $\mathrm{K}_{2} \mathrm{O}$ & & & 2.59 & 3.46 & 4.17 & 3.55 & 1.77 & 3.90 \\
\hline & $\mathrm{TiO}_{2}$ & & & 1.03 & 0.72 & 1.46 & 1.13 & 0.66 & 1.30 \\
\hline & $\mathrm{H}_{2} \mathrm{O}^{2}$ & & & 15.71 & 16.40 & 15.60 & 15.36 & 15.50 & 17.03 \\
\hline
\end{tabular}

Note: (1) Hole 332A, microprobe analysis of palagonite (Scarfe and Smith, 1977). (2) Site 335, microprobe analysis of palagonite (Scarfe and Smith, 1977). (3) Sample $417 \mathrm{~A}-24-3,40-44 \mathrm{~cm}$. (4) Sample $417 \mathrm{~A}-26-4,95-97 \mathrm{~cm}$. (5) Sample 417 A-29-4, $24-27 \mathrm{~cm}$. (6) Sample $417 \mathrm{~A}-30-1,32-37 \mathrm{~cm}$. (7) Sample $417 \mathrm{~A}-32-1,118-121 \mathrm{~cm}$. (8) Sample $417 \mathrm{~A}-32-2,28-31 \mathrm{~cm}$. All analyses of Hole $417 \mathrm{~A}$ samples were made by $\mathrm{X}$-fluorescence and atomic absorption $(\mathrm{Si}, \mathrm{Na})$, plus wet analysis for $\mathrm{Fe}_{2} \mathrm{O}_{3}$ and impulsion titrimetry for $\mathrm{CO}_{2}$ (analyst: R. Montanari, Laboratoire de Pétrologé, Nancy University). Calcite has been eliminated in these analyses to facilitate comparisons (corrected analyses).

Frey, F.A., Haskin, M.A., Poetz, J. and Haskin, L.A., 1968. Rare earth abundances in some basic rocks, J. Geophys. Res., v. 73, p. 6085-6098.

Frey, F.A., Bryan, W.B., and Thompson, G., 1974. Atlantic ocean floor: geochemistry and petrology of basalts from Leg 2 and 3 of the DSDP, J. Geophys. Res., v. 79, p. 5507-5527. lanthanides dans les roches par activation neutronique, $C . R$. Acad. Sci. Paris, v. 284, p. 1139-1142.

Dymond, J., 1973. K-Ar dating of basalt from DSDP 163, Leg 16, DSDP. In van Andel, T.H., Heath, C.R., et al., Initial Reports
TABLE 6

Cationic and Structural Formulas of Three Palagonites From Hole 417A (after the data of Table 5)

\begin{tabular}{lrrrrrr}
\hline & $417 \mathrm{~A}-24-3,40-44 \mathrm{~cm}$ & \multicolumn{2}{c}{$417 \mathrm{~A}-26-4,95-97 \mathrm{~cm}$} & \multicolumn{2}{c}{$417 \mathrm{~A}-30-1,32-37 \mathrm{~cm}$} \\
\hline $\mathrm{Si}$ & 7.233 & 8.000 & 7.167 & 8.000 & 7.132 & 8.000 \\
$\mathrm{Al}^{(4)}$ & 0.767 & & 0.833 & & 0.868 & \\
$\mathrm{Al}^{(6)}$ & 1.957 & & 1.854 & & 2.098 & \\
$\mathrm{Fe}^{3+}$ & 1.082 & 4.281 & 1.070 & 4.362 & 1.062 & 4.240 \\
$\mathrm{Fe}^{2+}+\mathrm{Mn}$ & 0.078 & & 0.102 & & 0.065 & \\
$\mathrm{Mg}$ & 1.164 & & 1.336 & & 1.015 & \\
$\mathrm{Ca}$ & 0.016 & & 0.110 & & 0.044 & \\
$\mathrm{Na}$ & 0.328 & 0.842 & 0.454 & 1.242 & 0.448 & 1.178 \\
$\mathrm{~K}$ & 0.498 & & 0.678 & & 0.686 & \\
\hline
\end{tabular}

Note: Sample 417A-24-3,40-44 $\mathrm{cm}=\left(\mathrm{Ca}_{0.03} \mathrm{Na}_{0.47} \mathrm{~K}_{0.71}\right)_{0.7}\left(\mathrm{Al}_{0.49} \mathrm{Fe}_{0.27}^{3+} \mathrm{Fe}_{0.02}^{2+}\right.$ $\left.\mathrm{Mg}_{0.29}\right)_{4}\left(\mathrm{Si}_{0.904} \mathrm{Al}_{0.096}\right)_{8}{ }_{20}(\mathrm{OH})_{4} ;$ Sample $417 \mathrm{~A}-26-4,95-97 \mathrm{~cm}=\left(\mathrm{Ca}_{0.16}\right.$ $\left.\mathrm{Na}_{0.65} \mathrm{~K}_{0.97}\right)_{0.7}\left(\mathrm{Al}_{0.46} \mathrm{Fe}_{0.27}^{3+} \mathrm{Fe}_{0.03}^{2+} \mathrm{Mg}_{0.33}\right)_{4}\left(\mathrm{Si}_{0.895} \mathrm{Al}_{0.105}\right)_{8}{ }_{20}(\mathrm{OH})_{4}$; Sample 417A-30-1, 32-37 $\mathrm{cm}=\left(\mathrm{Ca}_{0.06} \mathrm{Na}_{0.64} \mathrm{~K}_{0.98}\right)_{0.7}\left(\mathrm{Al}_{0.52} \mathrm{Fe}_{0.27}{ }^{3+} \mathrm{Fe}_{0.02}{ }_{2+}^{+}\right.$ $\left.\mathrm{Mg}_{0.25}\right)_{4}\left(\mathrm{Si}_{0.891} \mathrm{Al}_{0.109}\right)_{8}{ }_{20}(\mathrm{OH})_{4}$.



Figure 12. Plots of $\mathrm{SiO}_{2}$ versus $\mathrm{K}_{2} \mathrm{O}$, weight per cent. Open squares $=$ fresh glasses from Leg $3(3-19)$, Leg $51\left(F_{1}\right.$, $\left.F_{2}, F_{3}\right)$, and $\operatorname{Leg} 37\left(F_{4}, F_{5}\right)$. Solid squares = palagonites from Leg 3 (3-19) and Leg 51, Hole 417A. See Tables 4 and 5 .

of the Deep Sea Drilling Project, v. 16: Washington (U.S. Government Printing Office), p. 651-666.

Ehrlich, A.M., 1968. Rare earth abundances in manganese nodules, Ph. D. Thesis. M.I.T., Cambridge, Massachusetts.

Hart, R., 1976. Progressive alteration of the oceanic crust. In Yeats, R.S., Hart, S.R., et al., Initial Reports of the Deep Sea Drilling Project, v. 34: Washington (U.S. Government Printing Office), p. 301-335.

Hay, R.L. and Iijima, A., 1968. Petrology of palagonite tuffs of Koko craters, Hawaii, Contrib. Mineral Petrol., v. 17, p. 141-154.

Hogdahl, O.T., Melson, S., and Bowen, V., 1968. Neutron activation analysis of lanthanide elements in seawater, $A d v$. Chem., v. 73, p. 308-325.

Juteau, T., Bingöl, F., Noack, Y., Whitechurch, H., Hoffert, M., Wirrmann, D., and Courtois, C., 1979. Preliminary results: mineralogy and geochemistry of alteration products in Leg 45 basement samples. In Melson, W.G., Rabinowitz, P.D., et al., Initial Reports of the Deep Sea Drilling Project, v. 45: Washington (U.S. Government Printing Office), p. 613-646.

Lofgren, G., 1971. Spherulitic textures in glassy and crystalline rocks, J. Geophys. Res., v. 76, p. 5635-5648. 
TABLE 7

Mobility of Major Oxides (grams $/ 100 \mathrm{~cm}^{3}$ ) After Palagonitization of Fresh Glasses

\begin{tabular}{|c|c|c|c|c|}
\hline & (1) & (2) & (3) & (4) \\
\hline $\mathrm{O}_{2}$ & -47.5 & -44.2 & -37.3 & -27.9 \\
\hline $\mathrm{Al}_{2} \mathrm{O}_{3}$ & -21.6 & -19.5 & -3.2 & -3.6 \\
\hline $\mathrm{FeO}$ & +5.3 & +6.6 & -8.3 & -8.4 \\
\hline $\mathrm{MgO}$ & -12.9 & -18.4 & -10.0 & -7.8 \\
\hline $\mathrm{aO}$ & -30.0 & -30 & -29 & -32.4 \\
\hline $\mathrm{a}_{2} \mathrm{O}$ & -4.9 & -3.2 & -3.7 & -4.0 \\
\hline $\mathrm{K}_{2} \mathrm{O}$ & +5.2 & +5.2 & +8.8 & +5.8 \\
\hline $\mathrm{TiO}_{2}$ & +1.2 & +0.9 & -1.4 & -2.0 \\
\hline
\end{tabular}

Note: $\mathrm{FeO}$ as total iron. (1) Leg 37, Hole $332 \mathrm{~A}, 3.5$ m.y.B.P., after the analysis of Scarfe and Smith (1977), see Tables 4 and 5. (2) Leg 37, Hole 335, 9 m.y.B.P., after the analysis of Scarfe and Smith (1977), see Tables 4 and 5. (3) Leg 51, Hole 417A, 110 m.y.B.P., after our analyses C-10 and F1 (see Tables 4 and 5). (4) Leg 51, Hole 417A, 110 m.y.B.P., after our analyses A-11 and F1 (see Tables 4 and 5).

TABLE 8

Comparison of the Rates of Chemical

Exchanges During Palagonitization in the Same Samples as in Table 7, in $10^{-9}$ $\mathrm{g} / \mathrm{cm}^{3} / \mathrm{yr}$

\begin{tabular}{lllll}
\hline & \multicolumn{1}{c}{$(1)$} & \multicolumn{1}{c}{$(2)$} & \multicolumn{1}{c}{$(3)$} & $(4)$ \\
\hline $\mathrm{SiO}_{2}$ & -135 & -49 & -3.4 & -2.5 \\
$\mathrm{Al}_{2} \mathrm{O}_{3}$ & -62 & -22 & -0.3 & -0.3 \\
$\mathrm{FeO}$ & +15 & +7.3 & -0.8 & -0.8 \\
$\mathrm{MgO}$ & -37 & -20 & -0.9 & -0.7 \\
$\mathrm{CaO}$ & -86 & -33 & -2.7 & -2.9 \\
$\mathrm{Na}_{2} \mathrm{O}$ & -14 & -3.5 & -0.3 & -0.4 \\
$\mathrm{~K}_{2} \mathrm{O}$ & +15 & +5.8 & +0.8 & +0.5 \\
$\mathrm{TiO}_{2}$ & +3.4 & +1.0 & -0.1 & -0.2 \\
\hline
\end{tabular}

Note: $\mathrm{FeO}$ as total iron.

Moore, J.G., 1966. Rate of palagonitization of submarine basalt adjacent to Hawaii, U.S. Geol. Surv. Prof. Paper, 550D, p. D163-D171.

Muffler, L.J.P., Short, J.M., Keith, T.E.C., and Smith, V.C., (1969). Chemistry of fresh and altered basaltic glass from Hound Island Volcanics, Southeastern Alaska, Am. J. Sci., v. 267, p. 196-209.

Scarfe, C.M. and Smith, D.G.W., 1977. Secondary minerals in some basaltic rocks from DSDP Leg 37, Canadian J. Earth Sci., v. 14, p. 903-910.

Smith, R.E., 1967. Segregation vesicles in basaltic lava, Am. J. Sci., v. 265 , p. 696-713.
TABLE 9

Chemical Analysis of Fresh Pillow Cores and Correction After Elimination of Calcite

\begin{tabular}{|c|c|c|c|c|}
\hline & & (1) & (2) & (3) \\
\hline & & D 15 & D 16 & D 17 \\
\hline \multirow{13}{*}{ 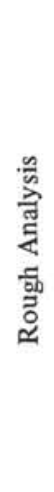 } & $\mathrm{SiO}_{2}$ & 47.56 & 47.58 & 48.15 \\
\hline & $\mathrm{Al}_{2} \mathrm{O}_{3}$ & 14.83 & 15.91 & 16.56 \\
\hline & $\mathrm{Fe}_{2} \mathrm{O}_{3}$ & 10.30 & 10.00 & 9.24 \\
\hline & $(\mathrm{FeO})^{3}$ & $(6.54)$ & (5.96) & (6.17) \\
\hline & $\mathrm{MnO}$ & 0.10 & 0.11 & 0.10 \\
\hline & $\mathrm{MgO}$ & 6.53 & 6.52 & 7.57 \\
\hline & $\mathrm{CaO}$ & 13.85 & 13.03 & 12.88 \\
\hline & $\mathrm{Na}_{2} \mathrm{O}$ & 2.44 & 2.46 & 2.17 \\
\hline & $\mathrm{K}_{2} \mathrm{O}$ & 0.25 & 0.06 & 0.05 \\
\hline & $\mathrm{TiO}_{2}$ & 1.48 & 1.42 & 1.15 \\
\hline & L.I. ${ }^{2}$ & 2.66 & 2.85 & 2.07 \\
\hline & $\left(\mathrm{CO}_{2}\right)$ & $(1.86)$ & $(0.26$ & $(0.11)$ \\
\hline & Total & 99.99 & 99.94 & 99.94 \\
\hline \multirow{12}{*}{ 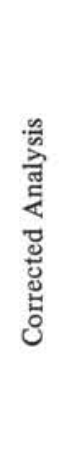 } & $\mathrm{SiO}_{2}$ & 49.67 & 47.82 & 48.30 \\
\hline & $\mathrm{Al}_{2} \mathrm{O}_{3}$ & 15.49 & 16.01 & 16.61 \\
\hline & $\mathrm{Fe}_{2} \mathrm{O}_{3}$ & 3.20 & 3.41 & 2.39 \\
\hline & $\mathrm{FeO}$ & 6.80 & 6.00 & 6.19 \\
\hline & $\mathrm{MnO}$ & 0.10 & 0.11 & 0.10 \\
\hline & $\mathrm{MgO}$ & 6.82 & 6.56 & 7.59 \\
\hline & $\mathrm{CaO}$ & 11.99 & 12.78 & 12.78 \\
\hline & $\mathrm{Na}_{2} \mathrm{O}$ & 2.55 & 2.48 & 2.18 \\
\hline & $\mathrm{K}_{2} \mathrm{O}$ & 0.25 & 0.06 & 0.05 \\
\hline & $\mathrm{TiO}_{2}$ & 1.54 & 1.43 & 1.15 \\
\hline & $\mathrm{H}_{2} \mathrm{O}^{2}$ & 0.84 & 2.61 & 1.97 \\
\hline & $\mathrm{Fe}_{2} \mathrm{O}_{3} / \mathrm{FeO}$ & 0.47 & 0.57 & 0.39 \\
\hline
\end{tabular}

Note: $\mathrm{Fe}_{2} \mathrm{O}_{3}=$ Total iron. L.I. $=$ lost by ignition. (1) Sample 417D-30-2, 43-45 cm. (2) Sample 417D-39-3, 12-18 cm. (3) Sample 417D-42-4, 72-77 cm. Analysis made by $\mathrm{X}$-fluorescence and atomic absorption $(\mathrm{Si}, \mathrm{Na})$, wet analysis for $\mathrm{Fe}_{2} \mathrm{O}_{3}$, and impulsion titrimetry for $\mathrm{CO}_{2}$ (analyst: R. Montanari, Laboratoire de Petrologie, Nancy University). Corrected analysis after elimination of calcite.

Thompson, G., 1973. A geochemical study of the low temperature interaction of sea-water and oceanic igneous rocks, EOS, v. 54, p. 1015-1019.

Treuil, M., Jaffrezic, H., Deschamps, N., Derre, C., Guichard F., Joron, J.L., Pelletier, B., Courtois, C., and Novotny, S., 1973. Analyse des lanthanides du hafnium, du scandium, du chrome, du manganèse, du cobalt, cu duivre et du zinc dans les minéraux et las roches par activation neutronique, J. Radioanal. Chem., v. 18, p. 55-68.

Trichet, J., 1970. Contribution à l'étude de l'altération expérimentale des verres volcaniques, Trav. Labo. Geol: E.N.S. Ulm, Paris, v. 170 , p. 1-170. 
TABLE 10

Chemical Analysis of Altered Pillow Cores and Correction After Elimination of Calcite

\begin{tabular}{|c|c|c|c|c|c|c|c|c|}
\hline & & $\begin{array}{l}(1) \\
2-10\end{array}$ & $\begin{array}{l}\text { (2) } \\
\text { A } 2\end{array}$ & $\begin{array}{l}\text { (3) } \\
\text { A } 3\end{array}$ & $\begin{array}{l}\text { (4) } \\
\text { A } 4\end{array}$ & $\begin{array}{l}\text { (5) } \\
\text { A } 5\end{array}$ & $\begin{array}{l}\text { (6) } \\
\text { A } 6\end{array}$ & $\begin{array}{l}\text { (7) } \\
\text { A } 8\end{array}$ \\
\hline \multirow{13}{*}{ 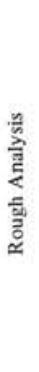 } & $\mathrm{SiO}_{2}$ & 47.42 & 46.84 & 41.03 & 47.96 & 46.90 & 47.34 & 45.34 \\
\hline & $\mathrm{Al}_{2} \mathrm{O}_{3}$ & 14.90 & 18.18 & 14.29 & 18.04 & 18.11 & 16.37 & 15.04 \\
\hline & $\mathrm{Fe}_{2} \mathrm{O}_{3}$ & 6.12 & 9.74 & 10.47 & 9.57 & 10.13 & 11.32 & 10.30 \\
\hline & $\mathrm{FeO}$ & 2.23 & $(1.41)$ & (1.91) & $(2.08)$ & $(2.72)$ & $(1.15)$ & $(1.19)$ \\
\hline & $\mathrm{MnO}$ & 0.11 & 0.13 & 0.13 & 0.15 & 0.15 & 0.15 & 0.15 \\
\hline & $\mathrm{MgO}$ & 7.31 & 5.04 & 5.20 & 4.88 & 4.92 & 5.01 & 5.37 \\
\hline & $\mathrm{CaO}$ & 11.65 & 5.19 & 12.76 & 5.44 & 7.16 & 7.47 & 11.83 \\
\hline & $\mathrm{Na}_{2} \mathrm{O}$ & 2.49 & 1.93 & 1.62 & 1.93 & 2.14 & 1.93 & 2.36 \\
\hline & $\mathrm{K}_{2} \mathrm{O}$ & 1.13 & 3.77 & 3.30 & 4.61 & 3.27 & 3.45 & 1.10 \\
\hline & $\mathrm{TiO}_{2}$ & 1.37 & 1.55 & 1.16 & 1.51 & 1.52 & 1.56 & 1.51 \\
\hline & L.I. & 4.72 & 7.28 & 10.12 & 5.47 & 5.46 & 5.33 & 6.81 \\
\hline & $\mathrm{CO}_{2}$ & $(0.70)$ & $(0.19)$ & $(5.24)$ & $(0.13)$ & $(0.59)$ & $(0.51)$ & $(2.41)$ \\
\hline & Total & 99.50 & 99.85 & 100.08 & 99.56 & 99.76 & 99.93 & 99.81 \\
\hline \multirow{12}{*}{ 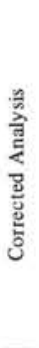 } & $\mathrm{SiO}_{2}$ & 48.43 & 47.11 & 46.53 & 48.31 & 47.65 & 48.17 & 48.06 \\
\hline & $\mathrm{Al}_{2} \mathrm{O}_{3}$ & 15.22 & 18.49 & 16.21 & 18.17 & 18.40 & 16.59 & 15.94 \\
\hline & $\mathrm{Fe}_{2} \mathrm{O}_{3}$ & 6.25 & 8.22 & 8.98 & 7.51 & 7.94 & 8.46 & 6.34 \\
\hline & $\mathrm{FeO}$ & 2.28 & 1.42 & 2.60 & 1.92 & 2.11 & 2.77 & 4.12 \\
\hline & $\mathrm{MnO}$ & 0.11 & 0.13 & 0.15 & 0.15 & 0.15 & 0.15 & 0.15 \\
\hline & $\mathrm{MgO}$ & 7.47 & 5.07 & 5.90 & 4.92 & 5.00 & 5.01 & 5.69 \\
\hline & $\mathrm{CaO}$ & 10.99 & 4.98 & 6.91 & 5.31 & 6.51 & 6.54 & 9.29 \\
\hline & $\mathrm{Na}_{2} \mathrm{O}$ & 2.54 & 1.94 & 1.84 & 2.16 & 2.17 & 1.97 & 2.50 \\
\hline & $\mathrm{K}_{2} \mathrm{O}$ & 1.15 & 3.79 & 3.74 & 4.64 & 3.32 & 3.52 & 1.17 \\
\hline & $\mathrm{TiO}_{2}$ & 1.40 & 1.56 & 1.32 & 1.52 & 1.54 & 1.59 & 1.60 \\
\hline & $\mathrm{H}_{2} \mathrm{O}$ & 3.39 & 7.13 & 5.53 & 5.36 & 4.95 & 4.97 & 4.66 \\
\hline & $\mathrm{Fe}_{2} \mathrm{O}_{3} / \mathrm{FeO}$ & 2.74 & 5.79 & 3.45 & 3.91 & 3.77 & 3.05 & 1.54 \\
\hline
\end{tabular}

Note: $\mathrm{Fe}_{2} \mathrm{O}_{3}=$ total iron. L.1. $=$ lost by ignition. (1) Leg 2, Hole 10 (Thompson, 1973). (2) Sample $417 \mathrm{~A}-24-3,103-107 \mathrm{~cm}$. (3) Sample 417A-25-2, 11-15 cm. (4) Sample 417 A-26-1, 22-24 cm. (5) $417 \mathrm{~A}-26-1,30-39 \mathrm{~cm}$. (6) Sample $417 \mathrm{~A}-28-2,89-95 \mathrm{~cm}$ (7) Sample $417 \mathrm{~A}-40-3,111-116 \mathrm{~cm}$. The six analyses of Hole $417 \mathrm{~A}$ made by $\mathrm{X}-\mathrm{ra}$ fluotescence and atomic absorption $(\mathrm{Si}, \mathrm{Na})$, wet analysis for $\mathrm{Fe}_{2} \mathrm{O}_{3}$, and impulsion titrimetry for $\mathrm{CO}_{2}$ (analyst: R. Montanari, Laboratoire de Pétrologie, Nancy University).

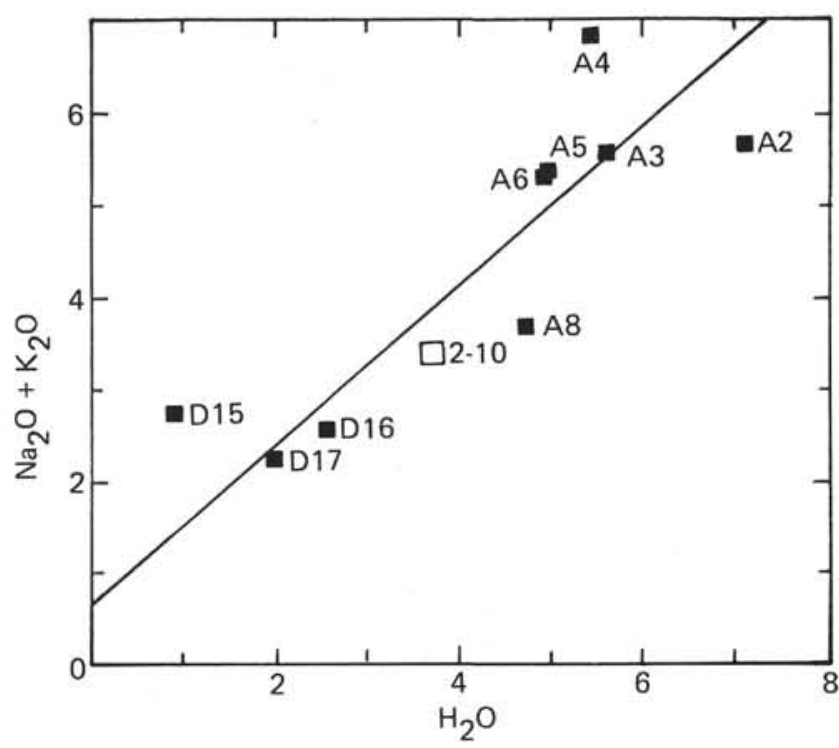

Figure 13. Plots of $\mathrm{H}_{2} \mathrm{O}$ versus $\left(\mathrm{Na}_{2} \mathrm{O}+\mathrm{K}_{2} \mathrm{O}\right)$, basaltic pillow cores (see Tables 9 and 10). Solid squares = samples from Leg 51: three fresh pillow cores from Hole $417 D(D 15, D 16$, and $D 17)$, and six altered pillow cores

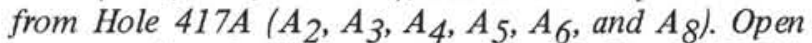
square $=$ altered pillow core from Leg 2, Site 10 (2-10).



Figure 14. Plots of $\mathrm{H}_{2} \mathrm{O}$ versus $\mathrm{Fe}_{2} \mathrm{O}_{3} / \mathrm{FeO}$ for the same samples (see Figure 13). 


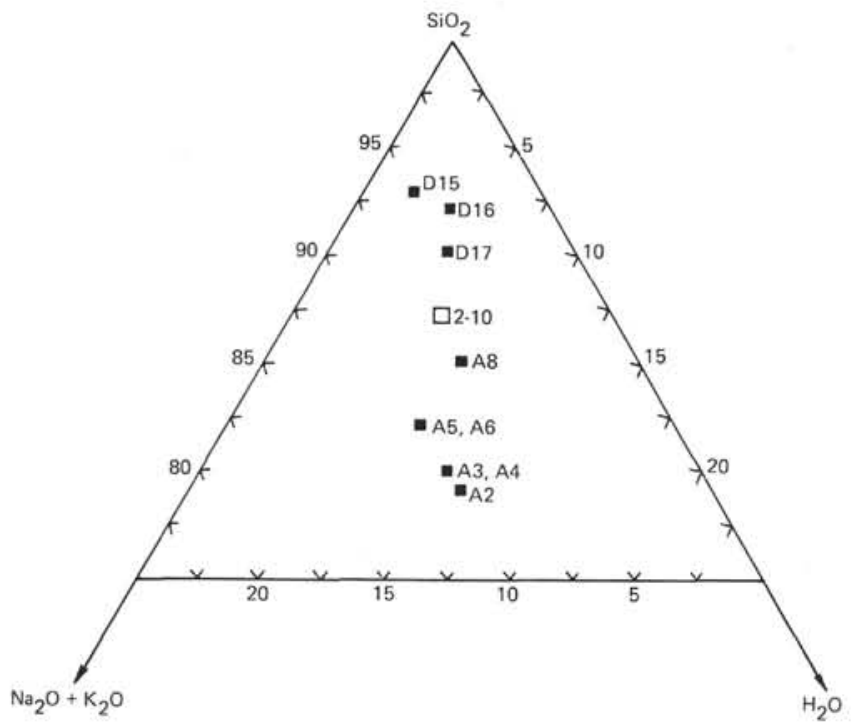

Figure 15. Plots in the triangle $\mathrm{SiO}_{2}-\left(\mathrm{Na}_{2} \mathrm{O}+\mathrm{K}_{2} \mathrm{O}\right)-\mathrm{H}_{2} \mathrm{O}$ for the same samples (see Figure 13).

TABLE 11

Mobility of Major Oxides (grams/100 $\mathrm{cm}^{3}$ )

After Alteration of Fresh Basaltic Pillow Cores

\begin{tabular}{lrrr}
\hline & \multicolumn{1}{c}{$(1)$} & \multicolumn{1}{c}{$(2)$} & \multicolumn{1}{c}{$(3)$} \\
\hline $\mathrm{SiO}_{2}$ & -18.4 & -22.0 & -2.1 \\
$\mathrm{Al}_{2} \mathrm{O}_{3}$ & -8.7 & -3.1 & +7.4 \\
$\mathrm{FeO}$ & -5.9 & -3.1 & -0.5 \\
$\mathrm{MgO}$ & -1.4 & -8.4 & -5.0 \\
$\mathrm{CaO}$ & -4.3 & -24.8 & -21.9 \\
$\mathrm{Na}_{2} \mathrm{O}$ & -0.7 & -1.7 & -1.4 \\
$\mathrm{~K}_{2} \mathrm{O}$ & +1.9 & +4.3 & +10.7 \\
$\mathrm{TiO}_{2}$ & -0.3 & +0.2 & +0.1 \\
$\mathrm{MnO}_{\mathrm{nO}}$ & -0.1 & -0.1 & +0.1 \\
$\mathrm{H}_{2} \mathrm{O}$ & +9.7 & +24.0 & +12.5 \\
\hline
\end{tabular}

Note: (1) Leg 2, Hole 10, altered core of a lava flow, $16 \mathrm{~m} . \mathrm{y}$ B.P. (Thompson, 1973). (2) Strongly altered lava, $80 \mathrm{~m} . \mathrm{y}$. B.P., after the analysis given by Thompson (1973). Leg 51 , Hole 417A, altered core of pillow, 110 m.y.B.P., after the average of Analyses 4, 5, and 6 of Table 10 and Analysis 1 of Table 9. Measured densities are: $\mathrm{d}=2.97$ for Analysis 4, 3.00 for Analysis 5, 3.02 for Analysis 6, and 3.03 for Analysis 1.
TABLE 12

Comparison of the Rates of Chemical Exchanges During Basalts Alteration $\left(10^{-9} \mathrm{~g} / \mathrm{cm}^{3} / \mathrm{yr}\right)$

\begin{tabular}{|c|c|c|c|}
\hline & (1) & (2) & (3) \\
\hline & -11.5 & -2.7 & -0.2 \\
\hline $\mathrm{Al}_{2} \mathrm{O}_{3}$ & -5.4 & -0.4 & +0.7 \\
\hline $\mathrm{FeO}$ & -3.7 & - & -0.05 \\
\hline $\mathrm{MgO}$ & -0.9 & -1 & -0.5 \\
\hline $\mathrm{CaO}$ & -2.7 & -3.1 & -2.0 \\
\hline $\mathrm{Na}_{2} \mathrm{O}$ & -0.4 & -0.2 & -0.1 \\
\hline $\mathrm{K}_{2} \mathrm{O}$ & +1.2 & +0.5 & +1.0 \\
\hline $\mathrm{TiO}_{2}$ & -0.2 & +0.2 & +0.01 \\
\hline $\mathrm{MnO}$ & -0.05 & -0.01 & +0.01 \\
\hline $\mathrm{H}_{2} \mathrm{O}$ & +6.1 & +3.0 & +1.1 \\
\hline
\end{tabular}

Note: $\mathrm{FeO}$ as total iron. Same samples as used in Table 11.

TABLE 13

Rare Earth Contents in Four Fresh Glassy Margins From Hole 417D, and Five Palagonitized Pillow Margins From Hole 417A

\begin{tabular}{lccccccccr}
\hline $\begin{array}{c}\text { Sample } \\
\text { (Interval in cm) }\end{array}$ & La & $\mathrm{Ce}$ & $\mathrm{Nd}$ & $\mathrm{Sm}$ & $\mathrm{Eu}$ & $\mathrm{Tb}$ & $\mathrm{Yb}$ & Lu & Total \\
\hline $417 \mathrm{D}-27-4,77-82$ & 0.86 & 3.25 & 2.30 & 0.79 & 0.29 & 0.24 & 1.19 & 0.22 & 9 \\
$417 \mathrm{D}-30-7,114-119$ & 0.92 & 4.43 & 4.2 & 1.17 & 0.47 & 0.37 & 2.0 & 0.37 & 14 \\
$417 \mathrm{D}-35-1,136-140$ & 1.10 & 5.13 & 3.9 & 1.35 & 0.48 & 0.35 & 1.43 & 0.27 & 14 \\
$417 \mathrm{D}-66-5,32-36$ & 1.17 & 6.0 & 5.9 & 1.95 & 0.78 & 0.6 & 2.47 & 0.45 & 19 \\
$417 \mathrm{~A}-26-4,95-97$ & 0.19 & 1.77 & 1.0 & 0.18 & 0.07 & 0.06 & 0.32 & 0.06 & 4 \\
$417 \mathrm{~A}-29-4,24-27$ & 0.27 & 2.4 & 1.4 & 0.22 & 0.09 & 0.07 & 0.30 & 0.05 & 5 \\
$417 \mathrm{~A}-30-1,32-37$ & 0.17 & 3.38 & 1.25 & 0.34 & 0.13 & 0.11 & 0.58 & 0.10 & 6 \\
$417 \mathrm{~A}-32-2,28-31$ & 0.71 & 5.18 & 3.21 & 0.81 & 0.31 & 0.23 & 1.19 & 0.21 & 12 \\
$417 \mathrm{~A}-32-5,77-82$ & 1.74 & 9.76 & 6.02 & 1.97 & 0.73 & 0.56 & 2.50 & 0.45 & 24 \\
\hline
\end{tabular}

Note: Analysis made by neutron activation (analyst: C. Courtois). 


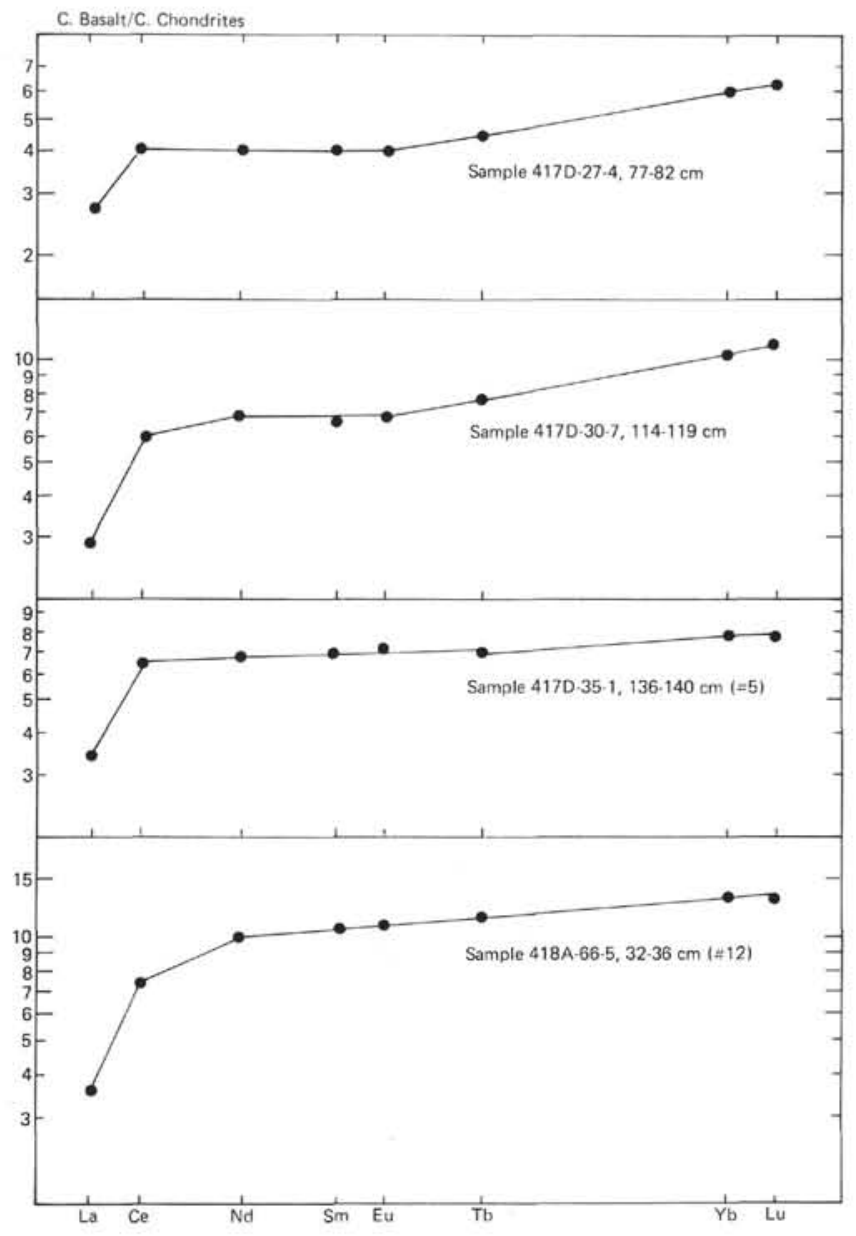

Figure 16. Rare-earth distribution in fresh glassy margins from pillow lavas of Hole $417 D$. Concentrations normalized to chondrites, logarithmic scale.

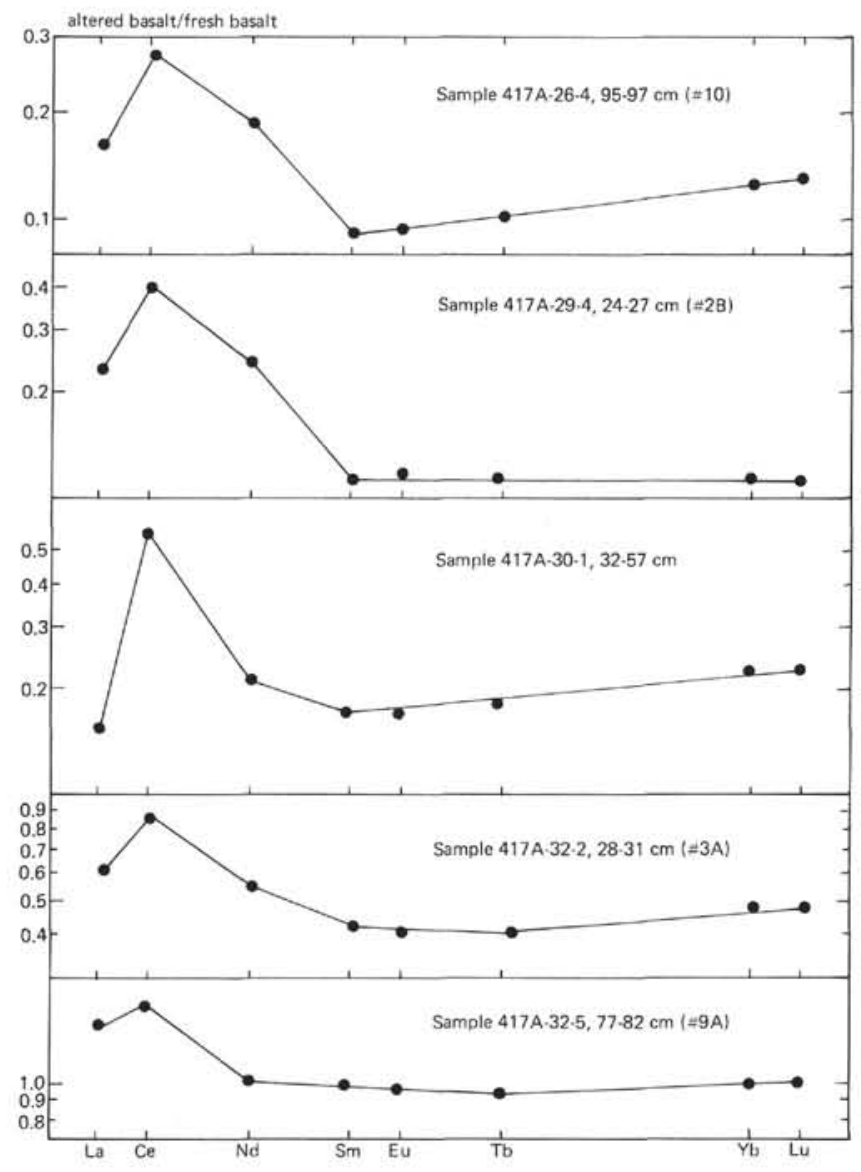

Figure 17. Rare-earth distribution in altered (palagonitized) glassy margins from pillow lavas of Hole 417A. Concentrations normalized to one of the fresh samples (Sample 417A-66-5, 32-36 cm, \#12), logarithmic scale. 



\section{PLATE}

Some characteristic macroscopic and microscopic features of basalts from Hole 417A.

Figure 1 Section of a pillow lava and its hyaloclastic matrix, showing the main characteristic features of pillow morphology: curved chilled margin, with a 2-cm thick altered yellowish groundmass (pale gray) and a 2-cm thick dark brown outer rim; radial veinlets filled with calcite, hematite, and chlorite; delicate green palagonite shards, elongated parallel to the pillow margin, set in a fine-grained matrix of the same material, and cemented by calcite. The plagioclase phenocrysts of the basalt are well visible. Notice that their size is drastically reduced in the chilled zone. (Sample 417A-24-2, \#6d). Core width: $6 \mathrm{~cm}$.

Figure 2 Hyaloclastic breccia, coming from a hyaloclastic horizon, interbedded between two pillow flows. Sample 417A-1-26-4, 33-48 cm. Core width: $6 \mathrm{~cm}$.

Figure 3 Nice exfoliation structure of palagonite rims, still attached to the pillow margin. Sample 417A-34-1, \# 5 . Core width: $6 \mathrm{~cm}$.

Figure 4 Central part of a plagioclase phyric pillow basalt showing the relationship between alteration and fracturation. Fracture 1, with its "dirty" calcite, is prior to alteration and has stopped its progression from Part A (completely altered) to Part B (fresh). Fracture 2, with "clean" calcite, crosscuts the altered part and is posterior to alteration (Sample 417A-24-1, \#6a). Core width: $6 \mathrm{~cm}$.

Figure 5 Palagonitic rim around a pillow fragment, set in a fine-grained hyaloclastic matrix. The morphology of the rim suggests a volume expansion during hydration of the glass. Sample 417A-30-5, \#9. Core width: $6 \mathrm{~cm}$.

Figure 6 Development of pinkish dioctahedral smectites in a plagioclase phenocryst. Thin section, $\times 20$, without analyzer. Sample 417A-28-5, 17-19 cm.

Figure 7 Thin concentric palagonitic rims in hyaloclastic elements. Thin section, $\times 20$. Sample 417A-26-2, $117-120 \mathrm{~cm}$. 
PLATE 1

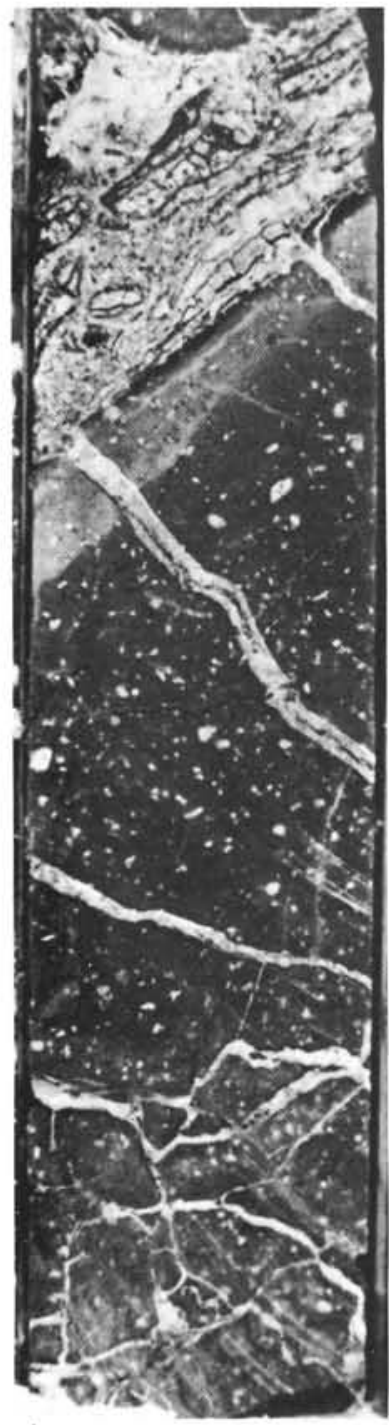

1

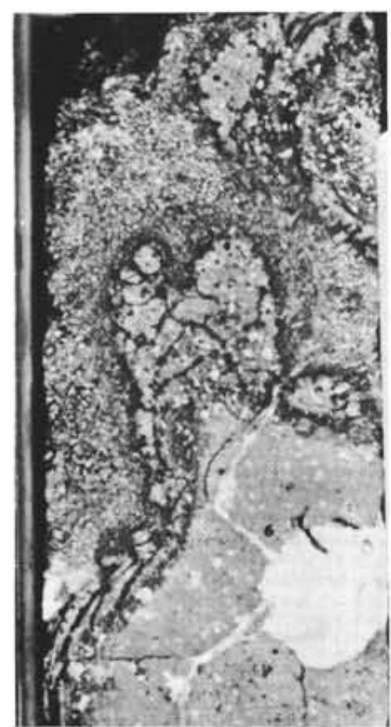

5
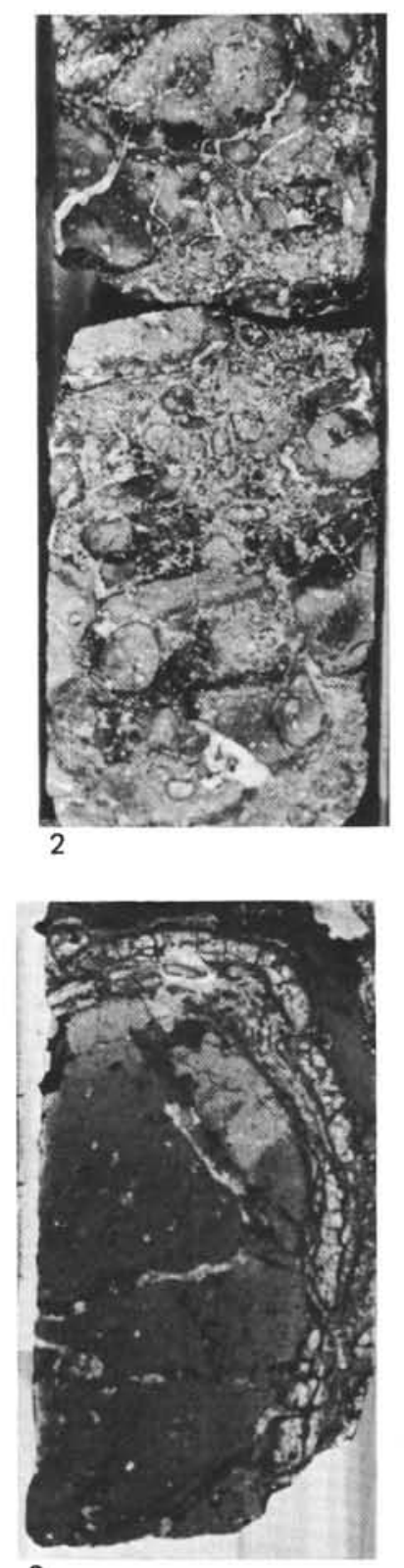

3

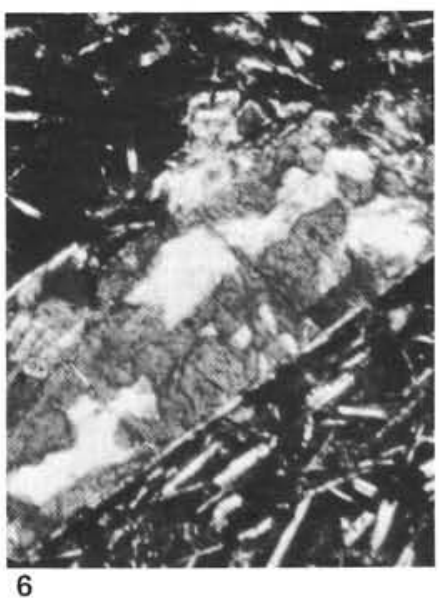

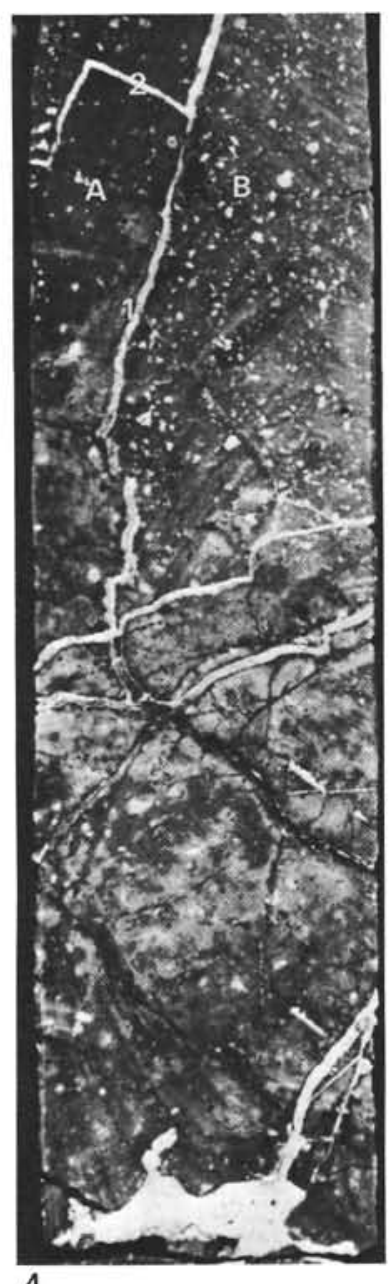

4

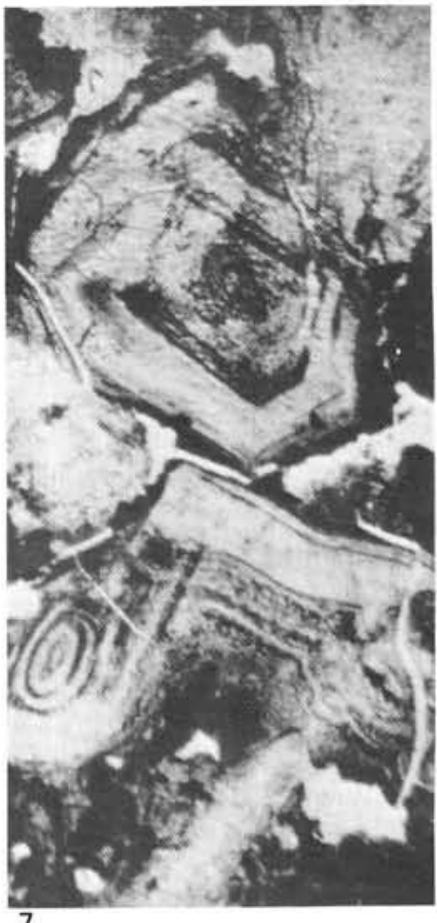


PLATE 2

Some characteristic macroscopic and microscopic features of basalts from Hole 417D.

Figure 1 Section of a pillow margin, showing a black and fresh glassy margin, $1 \mathrm{~cm}$ thick, and the calcitic matrix. Sample 417D-28-1, $88-110 \mathrm{~cm}$. Core width: $6 \mathrm{~cm}$.

Figure 2 Two adjacent plagioclase phyric pillow lavas, with their fresh glassy margins, and calcitic matrix. Sample 417D-28-3, 40-62 cm. Core width: $6 \mathrm{~cm}$.

Figure 3 Exfoliation of fresh glassy rim detached from a pillow margin. The void is filled with calcite. Sample 417D-27-3, 28-37 cm. Core width: $6 \mathrm{~cm}$.

Figure 4 Three successive fresh glassy rims in a pillow margin. The two outermost rims are delicately exfoliated, with calcite filling all the open voids. The innermost rim is still attached to the pillow margin. Sample 417D$28-3,72-78 \mathrm{~cm}$. Core width: $6 \mathrm{~cm}$.

Figure 5 Glassy fragments, hyaloclastic zone in a pillow margin. Thin concentric palagonitic layers develop parallel to the margins of the glassy fragments. The matrix is calcitic. Thin section, $\times 40$, without analyzer. Sample 417D-26-4, 132-135 cm.

Figure 6 Segregation vesicle. Residual magma has entered into the bubble, after retraction and escape of a part of the fluids, now replaced by calcite. Sample 417D-35-04, $03-06 \mathrm{~cm}$. Thin section, $\times 40$, without analyzer. 
PLATE 2

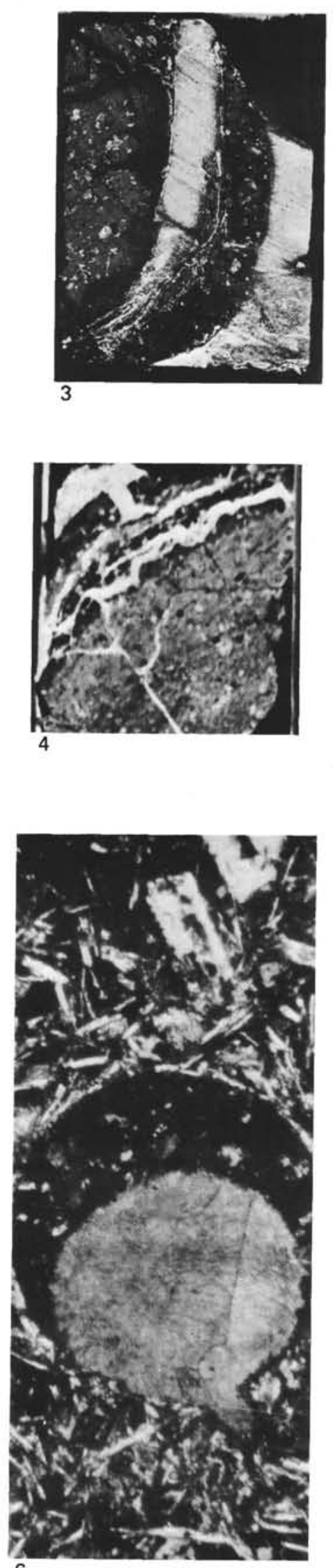